FILOLOGIJA 67, Zagreb 2016.

UDK 821.163.42'01-05 Držić, M. http://doi.org/10.21857/y54jof66nm Izvorni znanstveni članak Primljen 14.X.2016.

Ivan Lupić Prihvaćen za tisak 21.XI.2016.

Department of English, Stanford University

450 Serra Mall, Building 460

Stanford, CA 94305, United States of America

ilupic@stanford.edu

\title{
POSVETNE POSLANICE U DRUGOM IZDANJU DRŽIĆEVE TIRENE (1607)
}

Predmet su ovog rada različite posvetne poslanice koje se vežu uz drugo izdanje Tirene Marina Držića, objavljeno 1607: jedna, samo djelomično tiskana, upućena Vlahu Držiću te druga upućena kardinalu Silvestru Aldobrandiniju. Za poslanicu Aldobrandiniju dosad se mislilo da nikad nije tiskana jer je bila poznata samo u prijepisu Ivana Kukuljevića Sakcinskog iz 1840. koji je on sačinio iz neidentificiranog predloška. Nasuprot takvu uvjerenju, jedan primjerak tiskanog izdanja Tirene iz 1607. na koji se ovdje po prvi put skreće pozornost pokazuje da je poslanica Aldobrandiniju ipak bila tiskana, i to u cijelosti. Nadalje se dokazuje da je upravo taj sačuvani primjerak poslužio kao izravni predložak jednom rukopisu koji je sredinom osamnaestog stoljeća sastavio Miho Rastić, a za koji proučavatelji djela Marina Držića dosad također nisu znali. Konačno, dokazuje se da je Rastićev rukopis kasnije poslužio kao izravni predložak Kukuljevićevu prijepisu. Izravnom bibliografskom analizom svih preživjelih primjeraka zaključuje se da je Držićeva Tirena 1607. godine objavljena u samo jednom izdanju, ali u primjercima za koje su namijenjene različite posvetne poslanice. Iako su u novije vrijeme oživljena mišljenja da su Držićeva djela objavljena u Mlecima i u četvrtom izdanju, 1632. godine, pomnim pretresanjem postojećih dokaza te uz pomoć novih saznanja pokazuje se da je takva pretpostavka neutemeljena te da je izdanje iz 1630. treće i ujedno posljednje mletačko izdanje Držićevih djela. ${ }^{1}$

\footnotetext{
${ }^{1}$ Ovaj ogled napokon ispunjava najavu u Lupić 2012:898, bilj. 43, a još bi se težom mukom ostvario bez pomoći Irene Bratičević. Dvjema posvetnim poslanicama koje su ovdje predmet pridružujem treću, upućenu profesoru Stjepanu Damjanoviću u nadi da i za njegovog negdašnjeg đaka još ima spasa: praedicationibus et rationibus eloquiorum suorum convertit omnes illos ab erroribus...
} 


\section{Uvod}

Priređujući za Akademijinu seriju Stari pisci hrvatski novo izdanje Djela Marina Držića, do danas nezamijenjeno iako staro preko osamdeset godina, Milan Rešetar suočio se sa zanimljivom no vrlo zapetljanom zagonetkom vezanom uz rana izdanja Tirene. ${ }^{2}$ Držićeva pastirska drama objavljena je uz njegove Pjesni ujedno stavljene s mnozim druzim lijepim stvarmi u Mlecima tri puta: 1551. (Andrea Arrivabene / Niccolò Bascarini), 1607. (Francesco Bariletti) i 1630. godine (Marco Ginammi). Premda je Rešetar znao, na temelju starijih vijesti, da je Tirena prvi put tiskana 1551, točan izgled tog izdanja nije mu bio poznat jer se sve do prije desetak godina mislilo da od njega nije preživio nijedan primjerak. ${ }^{3} \mathrm{O}$ sadržaju prvog izdanja sudio je stoga Rešetar na temelju drugog izdanja, iz 1607. godine, pretpostavljajući da je drugo izdanje naprosto pretisak prvog izdanja, isto onako kao što je treće izdanje, iz 1630. godine, bilo svojevrsni pretisak drugoga ${ }^{4}$ No to drugo izdanje Tirene, iz 1607. godine, bilo je Rešetaru dostupno samo u jednom krnjem primjerku koji se čuva u knjižnici Hrvatske akademije znanosti i umjetnosti u Zagrebu. ${ }^{5} \mathrm{U}$ tom se primjer$\mathrm{ku}$, na nesreću, nije sačuvala upravo naslovnica, na čije je mjesto u devetnaestom stoljeću dubrovački prepisivač i kolekcionar Marko Marinović (1791-1871) umetnuo novi list te na njemu napisao: »TIRENA I SKASAGNE | sloxeno | pò Marinu Dàrxichju | Ù Mletzijeh | 1732. I polak Marca Ginami« (Slika 1). Netko je, međutim, nakon Marinovića godinu 1732. prepravio u 1607, a umjesto »Marca Ginami«, čije je ime prekriženo, napisao »Frana Bariletta «. ${ }^{6}$ Vodeći se činjenicom da je zajedno s Tirenom u ovom svesku uvezano i izdanje Držićevih Pjesni ujedno stavljenih s mnozim druzim lijepim stvarmi, čija naslovnica donosi podatke o tiskanju (»VBNE-

\footnotetext{
${ }^{2}$ Kao što sam drugdje pokazao (Lupić 2010), sva su kasnija izdanja Držićevih djela derivativna, a Rešetarovo nažalost manjkavo.

${ }^{3}$ Vijest o sačuvanim primjercima prvog izdanja Tirene i Pjesni u Biblioteca nazionale Braidense u Milanu donosi Stipčević (2007), koji godinu kasnije piše i pogovore pretisku: Držić 2008a i Držić 2008b.

${ }^{4}$ Za razliku od ranijih izdanja Tirene i Pjesni, izdanje iz 1630. sasvim je sjedinjena bibliografska cjelina jer nema odvojen naslovni list za Pjesni niti se njima započinje novi arak ili novi niz signatura, nego teku unutar istog arka (C) od lista C7r dalje.

${ }^{5}$ Rešetar ovaj primjerak navodi pod starom signaturom VII. a. 89 (Držić 1930:XX); nova je signatura R-769. Sve sačuvane primjerke starijih izdanja Držića o kojima pišem u ovom ogledu konzultirao sam uživo. Zelio bih zahvaliti na susretljivosti djelatnicima knjižnica u kojima se ti primjerci čuvaju.

${ }^{6}$ Rešetar je smatrao da je za Marinovićem križao pa ispravljao Kukuljević (Držić 1930:XX). Ja ne mislim da je riječ o Kukuljeviću. Slažem se, međutim, s Rešetarom da je novu naslovnicu napisao Marinović. Kako je Ginammi umro još u sedamnaestom stoljeću, godina 1732. u svakom je smislu pogrešna.
} 
ZIEH, M DC VII. I Polak Frana Bariletta«), Rešetar je točno zaključio da je Marinovićeva zamjenska naslovnica Tirene ispravljena s dobrim razlogom te je svoje izdanje utemeljio upravo na ovom primjerku, opisujući ga kao primjerak izdanja iz 1607. godine. ${ }^{7}$

Ne tako davni pronalazak neoštećenog primjerka izdanja Držićeve Tirene i njegovih Pjesni iz 1607. u Biblioteca comunale degli Intronati u Sieni potvrdio je Rešetarovo razlaganje (Slika 2). ${ }^{8}$ Sačuvana naslovnica također je potvrdila Rešetarovu pretpostavku da je izdanje iz 1607. utemeljeno na izdanju iz 1551. godine, jer se naime na naslovnicama i prvog i drugog izdanja kaže da je komedija Tirena prikazana u Dubrovniku 1548. godine te da u njoj »ulazi boj na način od moreške i tanac na način pastirski«. Drugo izdanje, kako bi se i očekivalo, još dodaje da je Tirena sada »iznovo prištampana«. No pronalazak potpunog primjerka drugog izdanja Tirene ne pomaže nam u rješavanju jednog nesvakidašnjeg problema. I oštećeni primjerak u Akademiji i neoštećeni primjerak u Sieni sadržavaju na prednjoj strani drugog lista (A2r) posvetnu poslanicu upućenu »Uzmožnomu i svake časti dostojnomu g. Vlahu Jera Držić«. Začudo, u oba primjerka druga strana ovog lista (A2v) ostala je prazna iako je jasno da se posveta prekida u pola rečenice, zapravo u pola riječi. I iz kustode na prednjoj strani drugog lista jasno je da je na sljedećoj stranici trebalo biti tiskano još teksta. Treći sačuvani primjerak Tirene i Pjesni iz 1607. tu nam također nije od pomoći. On se čuva u Nacionalnoj i sveučilišnoj knjižnici

\footnotetext{
${ }^{7}$ Držić 1930:XX-XXII. Manje je sretno Rešetar sudio o dopunama krnjem tekstu Novele od Stanca koje se nalaze na samom kraju sveska. Njih nije dopisao Đuro Matijašević, kako s velikom sigurnošću tvrdi Rešetar (XX), nego njegov nećak Ivan Marija Matijašević. U toj pogrešci Rešetara slijedi Slobodan Prosperov Novak u pogovoru pretisku ovog primjerka (Držić 1989). Pretisak bez dobrog opravdanja mijenja redoslijed tekstova u izdanju stavljajući Tirenu iza Pjesni, a na Marinovićevoj naslovnici ispravljena godina reproducirana je vrlo loše. Ruka Ivana Marije nalazi se samo u drugom dijelu sveska (Pjesni), a tu je on uz nadomjestak Noveli od Stanca unio poneki ispravak i dopunu i u neoštećeni dio teksta te brojevima označio Držićeve pjesme i numerirao svaki peti stih. Ispravljena paginacija pri kraju prvog dijela sveska (Tirena) te oznake dramskih prizora u tom dijelu (koje se, inače, u pretisku vide tek povremeno) ne potječu od Matijaševića.

${ }^{8}$ Na sačuvani primjerak upozorio je ravnatelj sienske knjižnice tijekom ondašnjeg znanstvenog skupa posvećenog Marinu Držiću, o čemu izvještava Muhoberac 2008, ali ne donosi podrobnije podatke. Primjerak se čuva pod signaturom VI/2 O 61, a u knjižnici se nalazi od njezina osnutka u osamnaestom stoljeću. Za primjerak se stoga moglo znati i prije, osobito zato jer je uvršten u kartični katalog knjižnice. Relevantna kartica, pisana rukom vjerojatno u devetnaestom stoljeću, glasi: »Darxich, | Marino. | Tirena, comedia in | lingua dalmatina. | Venetia, Barileti, | 1607. | in $12^{\circ}$ «. U novije je vrijeme prekrižen navedeni format, a umjesto njega je upisana šesnaestina. $O$ formatu ovog izdanja bit će više riječi ispod.
} 
u Zagrebu (signatura RIIC-16 -166 ), ali je još više oštećen nego Akademijin primjerak. Tireni uz naslovni list u ovom primjerku nedostaje i sljedeći list, na kojem bi se nalazila posveta uz ovo izdanje. Tako svi dosad poznati primjerci drugog izdanja Tirene ne pomažu da se objasni problem krnje posvetne poslanice.

Postoji, međutim, još jedan potpuno očuvan i dosad sasvim nepoznat primjerak izdanja Držićeve Tirene iz 1607. godine. Taj se primjerak, uvezan zajedno s izdanjem Držićevih Pjesni iz iste godine, kojima nedostaje naslovni list, čuva u Znanstvenoj knjižnici Odeskog nacionalnog sveučilišta I. I. Mečnikov u Ukrajini. On je zanimljiv ne zato što bi imao dovršenu poslanicu Vlahu Držiću, nego zato što umjesto te poslanice ima tiskanu sasvim drugu, cjelovitu poslanicu koju Maroje Vodopija upućuje talijanskom kardinalu Silvestru Aldobrandiniju na dan 26. travnja 1607. Za poslanicu Aldobrandiniju Rešetar je znao samo prema jednom rukopisu Ivana Kukuljevića Sakcinskog iz 1840. godine naslovljenu Cvětje pěsnikah ilirskih, ali smatrao je da poslanica nikad nije tiskana. ${ }^{9}$ Toj je krivoj pretpostavci pridonio sam Kukuljevićev rukopis, koji je na nekoliko mjesta Rešetara sasvim zbunio. Namjera je ove rasprave donijeti nešto podrobnije vijesti o novootkrivenom primjerku izdanja Tirene iz 1607, objasniti postojanje različitih posvetnih poslanica $u$ jednom te istom izdanju te konačno razriješiti dvojbe vezane uz predložak na temelju kojega je Kukuljević izradio svoj rukopis. Budući da su s Kukuljevićem počele i neke druge nedoumice, potrebno je pitanje ranih izdanja Tirene nešto temeljitije pretresti.

\section{Kukuljevićev kukolj}

Ono što su stariji dubrovački biografi znali o izdanjima Držićeve Tirene sažeto donosi Francesco Maria Appendini na početku devetnaestog stoljeća. On nabraja tri izdanja: prvo iz 1551. (bez spomena izdavača), drugo iz 1607. (Francesco Bariletti) i treće iz 1630. (Marco Ginammi). ${ }^{10}$ Oko pola stoljeća kasnije, uključivši izbor iz Držićeva pjesništva u antologiju Stari pjesnici hrvatski, Ivan Kukuljević spominje četiri izdanja Tirene, a razlikuje ih između ostaloga i prema posvetama koje se u njima navodno nalaze. ${ }^{11}$ Kukuljević bilježi da je Tirena prvi put izdana za života pjesnikova (1551)

\footnotetext{
${ }^{9}$ Kukuljevićev rukopis čuva se u Arhivu HAZU pod signaturom I. b. 86. U istoj godini sastavio je Kukuljević još jedan rukopis po sličnim načelima, a naslovio ga je Razno cvětje iz izversnih pěsnikah ilirskih (Arhiv HAZU, I. c. 28). U Kukuljevićevoj biblioteci ta su dva rukopisa bila pod jednom signaturom (broj 118).

${ }^{10}$ Appendini 1802-1803, II:222.

${ }^{11}$ Kukuljević 1858:74.
} 
»i posvetjena od njega Maru Makulji Puciću«; zatim da je izdana 1607. »kod Franje Bariletta, posvetjena po Maroji Vodopiću Silvestru Aldobrandinu kardinalu rimskomu «; treći put da je izdana 1630. »kod Marka Gjinama « te konačno, četvrti put, kod istog tiskara 1632. »posvetjena od nepoznatoga Vlahu Jeru Dàržiću«. K tomu dodaje Kukuljević i obavijest da su Držićeve Piesni ljuvene, kako ih on zove, tiskane zajedno s Tirenom 1551, 1607. i 1630. ${ }^{12}$ Za Držićeve Pjesni, dakle, Kukuljević ne navodi izdanje iz 1632. godine. U Bibliografiji hrvatskoj, objavljenoj dvije godine kasnije, Kukuljević ne spominje posvete, nego samo navodi izdanja Tirene: prvo iz 1551, drugo iz 1607, treće iz 1630. te četvrto iz 1632. Dok za prva tri izdanja navodi format, a za drugo i treće čak i broj stranica, za četvrto izdanje nema Kukuljević drugih podataka osim da je, kao i treće, objavljeno u Mlecima kod Ginammija. U natuknici za Držićeve Pjesni Kukuljević sada tvrdi da su i one izišle u četiri izdanja: 1551, 1607, 1630, 1632. ${ }^{13}$

Iz popisa Kukuljevićeve biblioteke saznajemo da je on posjedovao samo izdanja Tirene i Pjesni iz 1607. i 1630. godine, a po načinu na koji se ona navode može se zaključiti da su u oba slučaja Pjesni bile uvezane zajedno s Tirenom. ${ }^{14}$ To je očekivano jer su to jedina izdanja Držića za koja Kukuljević u Bibliografiji navodi brojeve stranica kao i format knjige (osmina za izdanje iz 1607. i šesnaestina za izdanje iz 1630). Budući da za prvo izdanje u Bibliografiji navodi format (osmina), ali ne navodi broj stra-

${ }^{12}$ Dok je glavni naslov izdanja iz 1551. Piesni Marina, Darxichia viedno stavgliene smnosim drusim liepim stvarmi, tekst pjesama počinje naslovom Piensi gliuuene Marina Darxichia, što se ponavlja i u izdanjima iz 1607. i 1630. Isto se tako dosljedno ponavlja omaška piensi umjesto piesni, što dokazuje ovisnost kasnijih izdanja o prvome. Začudo, pretisak ovog izdanja iz 2008. u impresumu je također naslovljen Pjesni ljuvene iako je to opis samo jednog dijela sadržaja (Držić 2008b). Za Držićevu posvetu Tirene Maru Makulji Puciću nije Kukuljević, dakako, morao poznavati prvo izdanje jer je ista posveta pretiskana i u drugom izdanju, nakon nove posvete. Isto je tako pretiskana Držićeva posveta »svojim prijateljem « ispred Pjesni. U trećem izdanju izostavljene su sve posvete.

${ }^{13}$ Kukuljević 1860:32, brojevi 327 i 328.

${ }^{14}$ Kukuljević 1867:73. Zapisi glase ovako: »53. Daržića Marina. Tirena Comedia, pjesme i pripovjest Venere. Venetia Marco Ginami 1630 16. - 54. Daržića Marina. Tirena komedia i piesni. V Bnecieh kod Frana Bariletto 1607 16. « Primjerci u HAZU (R769 za izdanje iz 1607. i R-226 za izdanje iz 1630) upravo su Kukuljevićevi primjerci, što se može ustanoviti provjerom starih signatura. Primjerak R-769 nosi staru signaturu S. III. 177, a primjerak R-226 staru signaturu S. III. 176. Te stare signature odgovaraju primjercima u Kukuljevićevoj biblioteci, kao što je vidljivo iz sačuvanih kataložnih kartica (Arhiv HAZU 653, Biblioteka Ivana Kukuljevića Sakcinskog, sv. IX, Slavica, kutija 6). Najnovijim Akademijinim signaturama prethodio je još jedan niz, aktualan kad je Rešetar priređivao svoje izdanje: VII. a. 89 i VII. a. 90. 
nica, može se pretpostaviti da je podatak preuzet iz druge ruke. ${ }^{15} \mathrm{Za}$ izdanje iz 1632, koje bi bilo četvrto po redu, Kukuljević međutim ne navodi ni format ni broj stranica, nego samo kaže da je objavljeno kod istog izdavača kao i prethodno, to jest kod Marca Ginammija. Tu Kukuljević niti opisuje niti preuzima nego će najprije biti da, kao što je već Rešetar posumnjao, izmišlja.

I sam očito zbunjen, Kukuljević je svojim podacima još više zbunio Franju Petračića, prvog priređivača Držićevih djela za seriju Stari pisci hrvatski. Iz Petračićeva popisa predložaka koji su mu bili dostupni jasno je da on nije imao primjerak izdanja iz 1551, dok je za izdanje iz 1607. imao upravo onaj krnji Akademijin primjerak koji je kasnije poslužio i Rešetaru, a koji je u Akademiju stigao upravo iz Kukuljevićeve biblioteke. Iako o tome ne govori eksplicitno, jasno je da se Petračić našao u škripcu kad je shvatio da se u oštećenom primjerku izdanja Tirene iz 1607. nalazi polovično tiskana posveta Vlahu Držiću, a da bi prema Kukuljevićevim navodima izlazilo da bi u tom izdanju trebala biti posveta kardinalu Aldobrandiniju. No kako je Kukuljević tvrdio da se posveta Vlahu Držiću nalazi u navodnom četvrtom izdanju, iz 1632. godine, Petračić je na brzinu zaključio kako je posveta Vlahu Držiću naknadno prilijepljena iz nepoznatog mu četvrtog izdanja u ovaj primjerak ionako odrpanog drugog izdanja iz 1607. To što u tom primjerku drugog izdanja nije bilo posvete kardinalu Aldobrandiniju, koja bi prema Kukuljevićevim izjavama tu trebala biti, nije Petračića mnogo brinulo. On nam samo kaže da je posvetu Aldobrandiniju, koju u izdanju u kojem mu je Kukuljević rekao da bi trebala biti nije našao, za tisak pripremio »po Kukuljevićevu prepisu «, o kojem ništa dalje ne saznajemo. ${ }^{16}$

Petračićevo ležerno prikazivanje predložaka na kojima je utemeljio svoje izdanje nije se nimalo svidjelo Rešetaru, koji brani Kukuljevića tako što svu krivnju za zbrku s posvetama ne sasvim pravedno svaljuje na Petra-

\footnotetext{
${ }^{15}$ Format ranih Držićevih izdanja navodi se vrlo neujednačeno. Kao što je vidljivo iz prethodne bilješke, izdanje Tirene iz 1607. u popisu Kukuljevićeve biblioteke opisuje se kao da je tiskano u šesnaestini, dok ga Kukuljević drugdje opisuje kao da je tiskano u osmini. I katalog Nacionalne i sveučilišne knjižnice u Zagrebu i katalog HAZU opisuju ovo izdanje kao izdanje u šesnaestini. No sveščići ovog izdanja sadržavaju po osam listova, tragovi lanaca na papiru su okomiti, a na vodeni žig nailazi se u gornjem unutarnjem kutu. Sve to odgovara osminskom formatu, a ne odgovara šesnaestinskom. Isto vrijedi i za prvo izdanje, iz 1551. Što se tiče trećeg izdanja, iz 1630, u kojem prvi sveščić obuhvaća osam listova, a ostali po šesnaest, i tu su tragovi lanaca okomiti te se na vodeni žig u pravilu nailazi u gornjem unutarnjem kutu. Sačuvani primjerci sva tri izdanja slične su veličine, 14 do $15 \mathrm{~cm}$ visoki i 9 do 10 centimetara široki.

${ }^{16}$ Držić 1875:IX. Ispod teksta posvete Aldobrandiniju Petračić piše: »Opazka. Ovo je iz rukopisa, prepisana g. Kukuljevićem« (64). Ni tu ne kaže kakav bi to rukopis bio.
} 
čića. Kukuljevića pak kori utoliko što smatra da četvrto izdanje Tirene, iz 1632. godine, nije vidio ni Kukuljević niti bilo tko drugi, odnosno da ono uopće ne postoji. ${ }^{17}$ Godinu 1632, tvrdi umjesto toga Rešetar, iskombinirao je Kukuljević zaveden Marinovićevom zamjenskom naslovnicom u primjerku Tirene iz 1607. Tu je iz Marinovićeve godine 1732. te njegova spomena Marca Ginammija Kukuljević, logikom koju Rešetar ne objašnjava, sklopio podatak o četvrtom izdanju, navodno objavljenu kod Ginammija 1632. godine.

Sve donedavno Rešetarov zaključak smatran je konačnim sudom. Kada je, međutim, Ennio Stipčević 2007. godine objavio svoj pronalazak primjeraka prvog izdanja Tirene i Pjesni u Biblioteca nazionale Braidense u Milanu, on je ujedno oživio i Kukuljevićevu blagopokojnu tvrdnju o izdanju iz 1632. te najavio mogućnost budućih pronalazaka. »To četvrto izdanje« koje spominje Kukuljević, piše Stipčević, »kasnijim istraživačima kao da je promaklo, pa se nakon Kukuljevića rijetko spominje, a ne spominju ga niti publikacije u kojima bi to bilo za očekivati.« Ne osvrćući se na probleme s Kukuljevićevim tvrdnjama koji su upravo prikazani, Stipčević zaključuje da »u svezi s bibliografikom Držićevih najranijih tiskovina možemo očekivati još iznenađenja ${ }^{18}$

Gotovo deset godina poslije iznenađenja još uvijek nema, ali se zato zbrka nastavlja. Milovan Tatarin, koji se u novije vrijeme dosta bavio Držićevim izdanjima, 2011. godine primjećuje da izdanje iz 1632. nije Kukuljevićeva izmišljotina. Da je ono doista postojalo, potvrdio je, smatra Tatarin, Aleksandar Stipčević u svom radu o inventaru mletačkog tiskara i knjižara Francesca Brogiollija iz 1678, u kojem se navode mnoge hrvatske knjige. ${ }^{19}$ Kako navodi Stipčević, »oko 1668. god. tiskara i sve što je ostalo od tvrtke Ginammijevih prelazi u vlasništvo tiskara Francesca Brogiollija «, koji je preuzeo »i sve nerasprodane knjige, uključujući i one na hrvatskom jeziku što ih je tiskala tvrtka Ginammi «. ${ }^{20}$ Aleksandar Stipčević svoj je rad objavio 2008. godine, dakle godinu dana nakon što je Ennio Stipčević oživio Kukuljevićeve tvrdnje, samo nije jasno što se Brogiollijevim inventarom zapravo potvrdilo. Naime, iz preslika relevantnih stranica iz Brogiollijeva inventara priloženih uz Stipčevićev rad sasvim je razvidno da se ondje uz dva spomena Tirene ne donosi godina izdanja, nego samo stoji »7 Tirena Comedia slauo $8^{\circ}$ « te $» 350$ Tirena Comedia In $8^{0}$ Slaua «. ${ }^{21}$ Sve što ovi za-

\footnotetext{
17 Sličnu je sumnju Rešetar izrazio i ranije; usp. Rešetar 1920:45.

18 Stipčević 2007:1061.

19 Tatarin 2011:100, bilj. 4; vidi također str. 28.

${ }^{20}$ Stipčević 2008:280.

${ }^{21}$ Za preslike stranica rukopisa prema kojima ovdje donosim prijepis vidi Stipče-
} 
pisi govore jest da se u Brogiollijevoj kući nakon njegove smrti našlo 7 neprodanih primjeraka Tirene, a u njegovoj knjižari 350. Oba puta izdanje Tirene opisuje se kao izdanje u osmini.

Očito pod oživljenim Kukuljevićevim utjecajem, iako Kukuljevića nigdje ne spominje, Stipčević u svom komentaru ovih zapisa kaže da je treće i četvrto izdanje Držićeve Tirene tiskao Marco Ginammi 1630. i 1632. godine, a da se zapis u Brogiollijevu inventaru odnosi na četvrto izdanje. „Čini se«, piše Stipčević, »da je Ginammi, videći da se treće izdanje brzo prodaje, upustio u tiskanje četvrtog izdanja i - preračunao se! Da li je tiskao preveliku nakladu ili se tržište zasitilo te knjige, to ne znamo, no činjenica jest da je od tog četvrtog izdanja 46 godina nakon što je objelodanjeno, ostalo Ginammiju 357 nerasprodanih primjeraka.« ${ }^{22}$ Pretpostavka nije sasvim logična. Naime, teško je zamisliti da bi se u dvije godine rasprodalo čitavo jedno izdanje Tirene, a da bi onda naglo došlo do potpunog zasićenja. Logičnija je pretpostavka da je riječ o Ginammijevu izdanju iz 1630, za koje sigurno znamo da je postojalo. ${ }^{23}$

Stipčević je, prema tome, puno ispravnije sudio u svom ranijem, sažetijem osvrtu na Brogiollijev popis. Tada je naime napisao: »U tiskari M. Ginammija tiskana je 1630. god. knjiga Tirena Comedia. Bilo je to treće i posljednje mletačko izdanje te knjige Marina Držića, pa je stoga izvan svake sumnje da je upravo to izdanje našao bilježnik koji je sastavio inventar Brogiollijeve ostavštine. « ${ }^{24}$ Ispravnost Stipčevićeva ranijeg suda, a onda i prilog potvrdi da nije bilo nikakvog izdanja Tirene iz 1632, nalazi potkrepu u još nekim uvidima do kojih se može doći proučavanjem stanja preživjelih primjeraka izdanja Tirene iz 1630. Akademijin primjerak, nekad u Kukuljevićevu vlasništvu, uvezan je još prije Kukuljevića zajedno s izdanjem Gundulićevih Suza sina razmetnoga iz 1703. ${ }^{25}$ Ta činjenica dobiva na

vić 2008:301, 304.

22 Stipčević 2008:293.

${ }^{23} \mathrm{O}$ problemu formata vidi bilješku 15 iznad. Barem jedan preživjeli primjerak izdanja iz 1630, koji ću uskoro spomenuti, katalogiziran je kao osminski. Treba također uzeti u obzir da sastavljač Brogiollijeva inventara Ribanje i ribarsko prigovaranje Petra Hektorovića, objavljeno u Bartolomea Ginammija 1638, opisuje kao osminu iako svi sveščići broje po šesnaest listova. Prema tome, podatak o formatu u Brogiollijevu inventaru nije u neskladu niti s izgledom niti s nekim drugim opisima izdanja iz 1630.

24 Stipčević 2005:97.

${ }^{25}$ Uz Akademijin primjerak izdanja iz 1630. Rešetaru je bio poznat još samo primjerak tog izdanja iz Arhiva Male braće u Dubrovniku (on ga navodi pod brojem 44, stari broj 1319; današnja je signatura 36/I/30). Dubrovački primjerak uvezan je samostalno, ali u novije vrijeme. U nadasve čudnoj bibliografiji Držićevih izdanja Sonja Martinović ne spominje nijedan primjerak koji se čuva u Hrvatskoj, nego samo primjerak koji je u međuvremenu lociran u Biblioteca nazionale Braidense u Milanu (Mar- 
zanimljivosti kad se shvati da je još jedan primjerak izdanja iz 1630. također uvezan s primjerkom Gundulićevih Suza iz 1703. Za taj se primjerak Tirene u nas dosad nije znalo. ${ }^{26}$ Gundulićeve Suze objavio je 1703. Bartolo Occhi, knjižar koji je inače početkom osamnaestog stoljeća u Veneciji prodavao preostala Ginammijeva izdanja, što je vidljivo iz popisa dostupnih naslova koje Occhi često dodaje svojim knjigama nastojeći tako prodati što više zaostalih primjeraka. ${ }^{27}$ Dakako da je moguće zamisliti slučajnost prema kojoj bi dva vlasnika neovisno jedan od drugoga odlučili uvezati zajedno upravo izdanje Držića iz 1630. i izdanje Gundulića 1703, no povezanost Occhijeve knjižarske djelatnosti i Ginammijevih izdanja navodi naprotiv na pomisao da su se ta dva izdanja baš tako uvezana mogla kupiti kod Occhija, odnosno da se Occhi nastojao riješiti starijih izdanja kombinirajući ih s novijima (ili, dakako, obrnuto, ovisno o tome za kojom je knjigom u danom trenutku bila veća potražnja). A to bi dalje značilo da je Occhi imao na raspolaganju neprodanih primjeraka izdanja Držića iz 1630, što bi se teško moglo pomiriti s nekim novim izdanjem iz 1632. za koje bi bilo interesa na tržištu.

Postoji, nadalje, još jedan dosad nezapažen primjerak izdanja Držićeve Tirene iz 1630. godine. On je zanimljiv iz sličnih razloga jer je, kao i dva već spomenuta, uvezan zajedno s drugim naslovima. Ovaj put riječ je mahom o izdanjima hrvatskih knjiga u nakladi Marca Ginammija. ${ }^{28}$ Te su knjige dospjele $u$ Bibliothèque Sainte-Geneviève $u$ Parizu, gdje su, kao što je i inače slučaj u stranim knjižnicama, katalogizirane kojekako. Većinom je riječ o izdanjima iz sedamnaestog stoljeća. Ta su razna hrvatska izdanja uveza-

tinović 2009:5). Signatura milanskog primjerka je Racc. Dramm. 2045. Kao i primjerci prvog izdanja Držića u Milanu, primjerak izdanja iz 1630. dio je dramske zbirke Corniani Algarotti (Raccolta Drammatica Corniani Algarotti), koja je u knjižnicu stigla 1891. godine. Marco Antonio Corniani Algarotti živio je od 1768. do 1845. Ni uvez ovog primjerka nije izvorni.

${ }^{26}$ Znanstvena knjižnica Odeskog nacionalnog sveučilišta I. I. Mečnikov, signatura 26/226. Primjerak je tadašnjem Novorosijskom sveučilištu prigodom osnutka (1865) darovao Viktor Ivanovič Grigorovič, kako mi je potvrdila Elena Viktorovna Polevščikova. Sadašnji uvez potječe iz kasnijeg vremena, ali je iz inventarnog broja jasno da su Držić i Gundulić bili uvezani zajedno i u trenutku kad je Grigorovič knjigu darovao Sveučilištu.

27 Popise prikazuje Stipčević 2005:88-106; vidi također Schmitz 1977:275-281. Jedan takav potpis priložen je i uz izdanje Suza iz 1703.

${ }^{28}$ Općenito o izdavačkoj djelatnosti Marca Ginammija vidi Napoli 1990, gdje se nažalost ne razmatraju izdanja na slavenskim jezicima. Kao što će biti jasno iz mog osvrta, krivo govori Miguel Battlori kada u uvodu spomenutoj monografiji kaže kako su slavenske knjige izostavljene "perché già studiate degli slavisti« (Napoli 1990:7; usp. s time str. 11, bilj. 2). Naše starije knjige izdane u Ginammija vape za preciznim bibliografskim opisima, a još uvijek nemamo čak ni njihov potpun i pouzdan popis. 
na u nekoliko svezaka vrlo rano, a sasvim sigurno prije sredine osamnaestog stoljeća. Tako je izdanje Tirene iz 1630. uvezano zajedno s izdanjem Gundulićevih Suza sina razmetnoga (Ginammi, 1622), Barakovićeve Jarule (Ginammi, 1636) te Pjesni ljubavi Dinka Ranjine (Ginammi, 1632). ${ }^{29}$ Osobito je vrijedno primijetiti da ovdje s Tirenom nalazimo uvezano ljubavno pjesništvo Dinka Ranjine u izdanju za koje se u nas dosad znalo samo po Occhijevim reklamnim popisima, ali se nije znalo ni za jedan preživjeli primjerak. ${ }^{30}$ Drago mi je da uz ovaj primjerak Pjesni ljubavi Dinka Ranjine mogu prijaviti još jedan preživjeli primjerak tog izdanja. On se nalazi u Bibliothèque Mazarine, također dobro poznatoj knjižnici u Parizu. ${ }^{31} \mathrm{Tu}$ je Ginammijevo izdanje Ranjininih Pjesni ljubavi uvezano zajedno s još dva Ginammijeva izdanja: Navišćenje muke (1628) fra Marka Marulića te, kako bi se i očekivalo, Pjesni razlike Dinka Ranjine (1632). ${ }^{32}$

Budući da je Držićeva Tirena u Bibliothèque Sainte-Geneviève uvezana s Ginammijevim izdanjima iz 1622, 1632. i 1636, a da u ostalim svescima ove knjižnice u kojima su uvezana Ginammijeva izdanja hrvatskih knjiga nalazimo uglavnom naslove objavljene dvadesetih i tridesetih godina sedamnaestoga stoljeća, sve do godine 1636, može se pretpostaviti da su ova izdanja nabavljena nakon 1636.33 To što među tako nabavljenim i uvezanim izdanjima nalazimo izdanje Tirene iz 1630, a ni traga kakvu izdanju te drame iz 1632, opet upućuje na zaključak da Tirena u Ginammija nije izdana nego samo jednom, i to 1630. godine. Konačno, u rukopisnom katalogu hrvatskih knjiga koje su se mogle kupiti u Veneciji u vrijeme kad je živio

${ }^{29}$ Od Marie-Hélène de La Mure iz Bibliothèque Sainte-Geneviève saznajem da je uvez sveska u kojem se nalazi Tirena prepoznatljiv kao uvez koji je naručivala Opatija Sainte-Geneviève, čija je knjižna zbirka poslužila kao temelj sadašnjoj biblioteci. Na početku Suza, koje su uvezane prve, nalazi se ex libris, inače unesen u sve knjige kad je 1753. pregledan cjelokupni inventar knjižnice. Znači da je svezak kakav je danas u istom sastavu bio sigurno prije 1753. godine.

30 Vidi Ranjina 1891:XVIII; Stipčević 2005:93; Stipčević 2008:287. Također je vrijedno znati za ovaj primjerak Gundulićevih Suza iz 1622. jer se dosad znalo samo za primjerak u Bibliothèque nationale de France, o kojem izvještava Kolendić 1956.

${ }^{31}$ Upravo je na temelju primjerka koji se čuva u Bibliothèque Mazarine izrađen u nas pretisak Knjižica krsta (1531) Šimuna Kožičića Benje; vidi Kožičić 1984:20-21.

32 Dosad se za Navišćenje muke navodilo kao prvo izdanje ono iz 1636. Vidi Kukuljević 1860:92, broj 1058; Marulić 1869:LXXVII; Schmitz 1977:75. Tako primjerkom iz Bibliothèque Mazarine dobivamo dokaz o dosad nepoznatom, ranijem izdanju ovog djela iz 1628. To objašnjava zašto se ovaj naslov javlja na Ginammijevu popisu knjiga iz 1633, što je zbunjivalo dosadašnje istraživače (usp. Stipčević 2008:289). Još jedan primjerak Navišćenja muke iz 1628. nalazi se u Bibliothèque nationale de France.

${ }^{33} \mathrm{O}$ drugim dosad nepotvrđenim izdanjima starih hrvatskih knjiga koja sam nedavno našao u pariškim bibliotekama dat ću podrobniji izvještaj drugdje. Tu ima mnogo novosti, osobito u vezi s Ginammijevim izdanjima. 
Marin Zlatarić (1753-1826), koji je taj katalog vlastitom rukom sastavio, navode se samo izdanja Tirene iz 1607. i $1630 .{ }^{34}$ Stoga mislim da iznenađenja vezanih uz izdanje iz 1632. neće biti zato što to izdanje ne samo da nitko nije vidio, kako primjećuje Rešetar, nego zato što ga doista nije ni bilo. ${ }^{35}$

\section{Kukuljevićevo cvijeće}

Za razliku od Petračića, Rešetar se nije dao zbuniti Kukuljevićevom opaskom da je posvetna poslanica Vlahu Držiću uključena tek u izdanje iz 1632. Odbacivši Kukuljevićeve tvrdnje o postojanju tog izdanja te primijetivši da list na kojem je ta poslanica polovično tiskana u izdanju Tirene za koje je ustanovio da je iz 1607. nije naknadno ulijepljen, kako je mislio Petračić, ${ }^{36}$ Rešetar se suočio s drugim problemom. Naime, kao i Petračić, on je za posvetnu poslanicu kardinalu Aldobrandiniju, za koju je pak Kukuljević ustvrdio da je prvi put tiskana uz drugo izdanje Tirene, znao jedino iz jednog Kukuljevićeva prijepisa. U Akademijinu primjerku drugog izdanja Tirene, kao što je već istaknuto, te poslanice nema, nego je ondje poslanica Vlahu Držiću te nakon nje poslanica koju je još uz prvo izdanje Maru Makulji Puciću uputio sam Marin Držić. Kukuljevićev pak prijepis pokazao se poprilično zagonetnim jer Rešetar nije mogao ustanoviti odakle je Kukuljević prepisivao.

Budući da posvetu kardinalu Aldobrandiniju iz pera Maroja Vodopije Rešetar nije našao ni u drugom izdanju iz 1607. ni u trećem iz 1630, on je zaključio da ona nikada nije tiskana. Iz posvete je, naime, jasno da nije mogla nastati u Držićevo vrijeme te da je sigurno nije moglo biti u prvom izdanju, iz 1551, od kojega do Rešetara nije došao nijedan primjerak. Vodopija navodi da je poslanicu pisao u Dubrovniku 26. travnja 1607, dakle

${ }^{34}$ Za Zlatarićev katalog vidi Museo Correr, Venecija, Biblioteca Cicogna, 3202, jedinica br. 37. U popisu upotrijebljenih izvora u drugom izdanju Della Bellina rječnika također se navode samo izdanja Tirene iz 1607. i 1630. (Della Bella 1785, I:13).

${ }^{35}$ Primjerak Tirene, bez ikakve vijesti o godini izdanja, spominje se $\mathrm{u}$ inventaru knjiga Dominika Bijankovića iz 1667. godine (Morović 1971:110-111).

${ }^{36}$ Budući da Akademijinu primjerku Tirene nedostaje originalni naslovni list, posljednji list u sveščiću (A8) izgubio je svoj parnjak pa je zato morao kasnije biti pričvršćen dodatnim komadom papira, koji se proteže ispod sveščića te je zalijepljen za drugi list (A2), odnosno za prvi preživjeli originalni list. Zbog tog zalijepljenog komada papira koji je vidljiv uz unutarnji rub A2 mogao je Petračić pomisliti da je tako naknadno umetnut drugi list (A2), a onda s njim i drugačija poslanica. No to sigurno nije slučaj jer je drugi list (A2) izravno povezan, kako bismo i očekivali, sa sedmim listom u sveščiću (A7). 
upravo u godini u kojoj je izašlo drugo izdanje Tirene. Rešetara je osobito zbunila bilješka na dnu početne stranice Kukuljevićeva prijepisa, u kojoj se kaže sljedeće: »Ova Comedia i ostale Pěsni koje slěde, biehu iz nova prištampane u Mletcieh po francesku Bariletti God. 1607 - i pripisane ^^su^ po franji Bariletti.«37 Zaključivši da je bilješku dodao sam Kukuljević, Rešetar je ponudio dvije pretpostavke: ili je Kukuljević pred sobom imao rukopis koji je prepisao odnosno dao prepisati mletački izdavač Bariletti za još jedno izdanje Tirene u 1607. godini, posvećeno kardinalu Aldobrandiniju, ili je Bariletti namjeravao kardinalu prikazati »samo jedan rukopisni, po svoj prilici kaligrafski napisani egzemplar toga Držićeva izdańa «. Kako u Kukuljevićevu prijepisu stvari dolaze drugim rasporedom nego u izdanju Tirene i Pjesni, Rešetar je zaključio da bi i u tom prerazmještanju na djelu trebalo vidjeti Barilettijevu ruku. »To bi bila još najbolja solucija ovog zamršenog pitanja «, zaključuje Rešetar, »pa nam je žao na Kukuljevića, ako već nije 'sačuvao' tu svoju maticu, - što nam nije bar kazao nešto više i nešto jasnije o njoj.«38

Jasno je iz priloga Dunje Fališevac, Slobodana Prosperova Novaka i Milovana Tatarina u Leksikonu Marina Držića da se ovom zamršenom pitanju više od pola stoljeća poslije u nas nije našlo bolje solucije od ove Rešetarove. ${ }^{39}$ Začudo, spomenuti prilozi propuštaju spomenuti jedan rad, a onda i jedan rukopis koji je tom radu predmet, unatoč tome što taj rad u nekoj mjeri pomaže da se ovo zamršeno pitanje razriješi. Riječ je o radu Marije Salzmann-Čelan »Marin Držić i Mavro Vetranović: O nekim rukopisima Posvetilišta Abramova«, objavljenu u časopisu Filologija Hrvatske akademije znanosti i umjetnosti. ${ }^{40}$ Salzmann-Čelan zanimali su rukopisi Vetranovićeva Posvetilišta Abramova, prikazanja koje je, kao što je poznato, u rukopisnoj tradiciji u jednom svom obliku pripisivano Marinu Držiću, pa ga tako nalazimo i u glavnom rukopisu Držićevih komedija u Pragu. ${ }^{41}$ Osvrćući se na najpotpuniji prikaz rukopisa i redakcija Posvetilišta, onaj Milana Rešetara, Salzmann-Čelan primjećuje da je Rešetar previdio rukopis 13293 Austrijske nacionalne knjižnice u Beču, u kojem se na početku nalazi Posvetilište, izrijekom pripisano Marinu Držiću. ${ }^{42}$ Uz Posvetilište u istom se rukopi-

\footnotetext{
${ }^{37}$ Rukopis Arhiva HAZU I. b. 86, list 19r.

${ }^{38}$ Držić 1930:XXVI.

${ }^{39}$ Vidi Novak et al. 2009, natuknice »Tirena« (Dunja Fališevac); »Aldobrandini, Silvestro« (Slobodan Prosperov Novak); »Vodopija (Vodopić), Marin (Maroje)« (Milovan Tatarin).

40 Salzmann-Čelan 1980/81.

${ }^{41}$ Rukopis T 4117 Slavenske knjižnice u Pragu, listovi 81v-86r.

42 Rešetar 1929; Salzmann-Čelan 1980/81:342-343. Kako Salzmann-Čelan uvjerljivo dokazuje, rukopis 13293 u Beču je bio već od sredine devetnaestog stoljeća.
} 
su nalaze i sva Držićeva djela koja su izdana tiskom za njegova života. Da urednicima Leksikona Marina Držića taj rukopis nije bio poznat, jasno je i iz toga što se on u natuknici o rukopisima Držićevih djela nikako ne spominje. To je doista neobično jer je rukopis uredno prisutan u objavljenim katalozima, a u Beču je morao biti i u Rešetarovo vrijeme. Osobito je nerazumljivo da Rešetar za ovaj rukopis nije znao kad inače u svom izdanju Držića upotrebljava neke rukopise iz Beča. ${ }^{43}$

Salzmann-Čelan ispravno je primijetila da je Kukuljevićev rukopis Cvětje pěsnikah ilirskih u vezi upravo s ovim bečkim rukopisom 13293. No kako je njoj predmet bilo Posvetilište, iz kojega je Kukuljević prepisao jedan dio, ostalo je nerazjašnjeno pitanje Kukuljevićeva prijepisa Tirene i zbrke koju je taj prijepis prouzročio u vezi s Vodopijinom poslanicom kardinalu Aldobrandiniju. Ostalo je također nerazjašnjeno tko je sastavio ovaj bečki rukopis Držićevih djela te kada je on točno nastao. Na temelju vodenog znaka Salzmann-Čelan je ustvrdila da bi se rukopis »mogao datirati najranije krajem 17 ili početkom 18 vijeka. «44 $\mathrm{U}$ ovom nam je slučaju, međutim, puno sigurniji vodič ono što o dubrovačkim rukopisima možemo saznati proučavajući njihove prepisivače, skupljače i sastavljače. ${ }^{45}$

Rukopis 13293 Austrijske nacionalne knjižnice podijeljen je u tri dijela, a svaki dio ima i svoj naslovni list. Na kraju se rukopisa nalazi sadržaj stvari koje se u njemu nalaze. Sva tri je naslovna lista kao i sadržaj bilo ispisao bilo dotjerao, kako se usporedbom s drugim dubrovačkim rukopisima može ustanoviti, Miho Rastić (1716-1768), od kojeg su se u različitim knjižnicama sačuvali rukopisi po svojim značajkama veoma slični ovom bečkom. U sadašnjem uvezu, koji je sigurno nastao nakon Rastićeva vremena, sadržaj rukopisa nalazi se na zadnjem listu (113). Taj je list, međutim, kako je iz originalne folijacije jasno, nekada bio uvezan na početku kao drugi list, dok je prvi list rukopisa u međuvremenu očito propao. Upravo bi se na tom prvom listu, da je preživio, našao podatak o tome tko je i kada prikupio i objedinio prijepise uključene u ovaj svezak jer Rastić takve podatke inače beziznimno bilježi na početku svojih rukopisa.

Prvi od tri dijela počinje s trećim listom, a pisala ga je, vjerojatno po Ra-

${ }^{43}$ Za (u pojedinostima netočan) kataloški opis vidi Schwarzenberg 1972:327-328. Za Hekubu je, primjerice, Rešetaru osnovni predložak bio jedan bečki rukopis (Držić 1930:XXXIV). O rukopisima Hekube vidi Bratičević i Lupić 2013:106-107; Lupić 2014:47.

44 Salzmann-Čelan 1980/81:344.

45 Nažalost, Salzmann-Čelan poprilično se zapetljala u svom prikazu rukopisa Posvetilišta i njihovih međusobnih odnosa, osobito u vezi s Ivanom Marijom Matijaševićem. Neka dakle budući istraživači budu na oprezu. 
stićevoj narudžbi, ruka iz sredine osamnaestog stoljeća koju i drugdje nalazimo u Rastićevim rukopisnim zbornicima. ${ }^{46}$ Ta je ruka napisala naslov »POSVETILISCTE | ABRAMOVO | PRIKAfANJE | skladjeno | Po MARINU DAER/CICHJU I DUBROVCIANINU «, a ispod toga je Rastić naknadno dodao »Litta Gospod. ${ }^{\text {va }}$ 1546. « Drugi dio rukopisa počinje na listu 25, gdje je naslov napisao sam Rastić: »TIRENA COMEDIA | SPIEVANA PO MARINU DARSCICHIU Ù । DUBROVNIKU PRIKASANA PRID | DUOROM Godiscta 1548. I U kojoj ula/i bojni nacin od Moreske, i tanaz I na nacin Pastierski«. Zatim je nešto niže na istoj stranici Rastić zapisao sljedeće: »Ova Comedia, i ostale Piesni koje sliede, biehu is nova I Prisctampane u Mlezieh po Francescu Bariletti I Godiscta Gosp: 1607.« Na samom pak dnu stranice Rastić je opet, sitnijim slovima, zapisao: »Is sctampana pripisano u Mlezieh I po Franu Bariletti«. Sam prijepis Tirene koji zatim slijedi nije iz Rastićeva pera, nego ga je sačinio Ivo Stulli (1733-1817), čija se ruka inače može naći $u$ istim rukopisima kao i Rastićeva. ${ }^{47}$ Stulli je prepisao i zadnji, treći dio rukopisa (od lista 72 dalje), u kojem su sadržane Držićeve pjesme te ostale, kraće stvari, uključujući Veneru i Stanca. Za ovaj je treći dio naslovnicu opet sastavio sam Rastić: »GLIUVENE PIESNI I SPIEVANE PO MARINU DARSCICHIU I Oko Litta Gospodinova 1549.«Prema dnu stranice Rastić dodaje napomenu »Pripisano is Sctampana«.

Jasno je iz ovog opisa da su, za razliku od Posvetilišta Abramova, Držićeva Tirena i Pjesni prepisane iz tiskanog izdanja. Jedino malo zbunjuje način na koji Rastić priopćava odakle je Stulli, vjerojatno po njegovu naputku, prepisivao. Na naslovnici Pjesni on bilježi samo podatak da je tekst prepisan iz tiskanog izdanja, dok na naslovnici Tirene bilježi da su i Tirena i Pjesni bile ponovno tiskane kod Francesca Barilettija 1607. godine. Kako bi objasnio odakle je njegov tekst prepisan, on na dnu naslovnice Tirene kaže,

46 Tom je rukom u cijelosti ispisan Rastićev zbornik koji se čuva u Nacionalnoj znanstvenoj knjižnici u Odesi (prije 2015. zvana Odeska državna znanstvena knjižnica M. Gorkoga) pod signaturom 10/4. Na naslovnom listu tog zbornika stoji da su u njemu okupljene Vetranovićeve tragedije i komedije "pripisane i složene [...] po zapovijedi gos. Miha Džona Resti« godine 1757. Ovaj je pisar, prema tome, Rastićev suvremenik. Rastićeva ruka u odeskom se kodeksu javlja samo na prvom, nenumeriranom listu, gdje je zabilježeno da kodeks obuhvaća 28 sveščića (»Libretti $28 \ll)$.

47 Vidi na primjer rukopis T 391 Slavenske knjižnice u Pragu, list 47 i dalje. Praški je prijepis datiran (1756), iz čega je dodatno jasno da je ova ruka iz istog vremena kao i Rastićeva. Stullijeva autografna pisma locirala je Irena Bratičević (vidi, na primjer, Državni arhiv Dubrovnik, Diplomata et acta saec. XVIII, sv. 149, 3188/56; sv. 190, 3355/124; sv. 192, 3357/27, itd.), a zatim njegovu ruku povezala s bečkim rukopisom. Ja se s tom identifikacijom u potpunosti slažem. Stulli je bio u diplomatskoj misiji na Kreti šezdesetih godina osamnaestog stoljeća, a od oko 1770. nadalje pisar je ureda za sol (scrivano del sale). Leksikograf Joakim Stulli (1730 - 1817) i Ivan Dominik Stulli (17281804) bili su mu braća. Usp. Brlek 1987:53-54, 104. 
kao i na naslovnici Pjesni, da je »Is sctampana pripisano", ali sada dodaje da je to štampano izdanje iz kojeg se prepisuje upravo ono objavljeno »u Mlezieh po Franu Bariletti«, čije je ime ovaj put malo prekrstio na svoju ruku. Sve je te podatke s Rastićeve naslovnice Tirene Kukuljević stopio u novo maslo, ali tako nespretno da je od izdavača Barilettija on nehotice načinio prepisivača (uz to što ga je i on dodatno prekrstio): »Ova Comedia i ostale Pěsni koje slěde, biehu iz nova prištampane u Mletcieh po francesku Bariletti God. 1607 - i pripisane ${ }^{\wedge}$ su^ $^{\wedge}$ po franji Bariletti.« 48

\section{Tirena u Odesi}

Da je Rastićev predložak na koji se Kukuljević oslanja bilo izdanje Tirene iz 1607. u kojem je doista tiskana Vodopijina poslanica kardinalu Aldobrandiniju, dokazuje primjerak ovog izdanja koji se čuva u Znanstvenoj knjižnici Odeskog nacionalnog sveučilišta I. I. Mečnikov pod signaturom 26/86 (vidi Slike 3, 4 i 5). ${ }^{49} \mathrm{Za}$ taj se primjerak dosad u nas nije znalo iako se za njega svakako moglo znati. On se naime uredno navodi u katalogu knjižnice Novorosijskog sveučilišta (današnjeg Odeskog sveučilišta) koji je tiskom objavljen još u devetnaestom stoljeću. ${ }^{50} \mathrm{U}$ taj su katalog, uređen

\footnotetext{
${ }^{48}$ Kažem nehotice zato što je Kukuljević kasnije (1858:74), kao što je već istaknuto, ustvrdio da je Tirena tiskom izdana drugi put 1607. »kod Franje Bariletta, posvetjena po Maroji Vodopiću Silvestru Aldobrandinu kardinalu rimskomu«. Za Rastićevo prepisivanje iz tiskanih knjiga može se, usporedbe radi, vidjeti što kaže u rukopisu $66 \mathrm{Ar}$ hiva Male braće u Dubrovniku uz prijepis Jeđupke: »Ova isvarsna Piesan Andrie Ciubranovichia biesce sctampana u Mletieh od Frana Bariletti Litta Gospodinova 1599. po Sapoviedi Mara Batitorovichia. A paka opeta bilaie risctampana Litta Gospodinova 1618. Jasamie pripiso is sctampana Libarza« (2r). Jeđupku je 1599. izdao Altobello Salicato. Rastić očito poznaje Barilettijevo izdanje iz 1618, a prema datiranoj Batitorovićevoj posvetnoj poslanici (1599) koja je u njemu pretiskana pogrešno pretpostavlja da je i prethodno knjiga izdana po Barilettiju. Izdao ju je opet i Ginammi 1632. godine.

${ }^{49}$ Primjerak je dostupan u elektronskom obliku na stranicama knjižnice ( $\mathrm{http}: / / \mathrm{ra}$ rebook.onu.edu.ua:8081/). Tu se također mogu naći izdanje Držića iz 1630. te Gundulićeve Suze iz 1703, primjerci koji su digitalizirani odvojeno iako su zapravo uvezani u jedan svezak (no svejedno su se u digitalizatima pomiješale neke stranice). Digitalizirani su dosad i ovi odeski primjerci izdanja hrvatskih i bosanskih knjiga: Stjepan Matijević, Ispovjedaonik (1630); Nikolica Bunić, Grad Dubrovnik vlastelom u trešnju (1667); Junije Palmotić, Kristijada (1670); Gabrijel Jurjević, Listi heroov (1675); Pavao Posilović, Naslađenje duhovno (1682); Matija Divković, Nauk krstjanski (1698); Baro Bettera, Oronta iz Cipra (1699; primjerak koji je od autora primio Đuro Grizić); Misal rimski, ur. Matej Karaman (1741).

${ }^{50}$ Kočubinskij 1878-1884:166, 168. Tirena se navodi u odjeljku 26 (»Произведения словесности славянскихъ племенъ, кромъ русскаго и польскаго«), pod brojem 86, gdje stoji: »Darxich M. Tirena, comedia prikasana u Dubrowniku godiscta 1548. Venetia 1607.«Format je naveden kao šesnaestina.
} 
prema tematskom rasporedu, uključene i one knjige koje su u knjižnicu došle iz zbirke poznatog poljskog slavista Andrzeja Kucharskog (17951862), a među njima i Držićeva Tirena iz 1607, uvezana, kako bismo i očekivali, zajedno s izdanjem Pjesni iz iste godine. Kucharski je Tirenu vjerojatno nabavio tijekom svog drugog studijskog putovanja po slavenskim zemljama, kada je posjetio i Dubrovnik (1829). ${ }^{51}$ Njegovu bogatu zbirku otkupilo je Novorosijsko sveučilište 1865. godine povodom svog osnutka. ${ }^{52}$ Za vrijeme boravka na Novorosijskom sveučilištu u Odesi od 1872. do 1874. Vatroslav Jagić imao je prilike upoznati se sa sadržajem sveučilišsne knjižnice. ${ }^{53}$ Među knjigama Kucharskoga našao se i dobro sačuvan primjerak Lekcionara Bernardina Splićanina, o kojem Jagić posebno izvještava, a koji je kasnije iskorišten - iako preko druge ruke - u Maretićevu izdanju Lekcionara. ${ }^{54}$ No Jagić ništa nije javio o primjerku Tirene iz 1607. godine niti o mnogim drugim primjercima starijih izdanja hrvatskih knjiga koji se ondje čuvaju. ${ }^{55}$

${ }^{51}$ O posjetu Kucharskoga Dubrovniku vidi Rapacka 1998:182. Iz rukopisne bilješke na unutarnjoj strani prednjih korica vidi se da je ova knjiga nekoć pripadala knjižnici talijansko-dubrovačke obitelji Frezza-Golubović (Nella Libreria della Famiglia Fre$z z a-G o l l u b o v i c h$ ). Broj 934 koji stoji na istom mjestu pisan je kasnije, drugom rukom, a istom rukom pisan broj nalazi se i u primjerku Bunićeve knjige Grad Dubrovnik vlastelom u trešnju, kojoj je Kucharski također bio vlasnik. Naslovni list Tirene imao je rukopisni ex libris koji je glasio Ex Bibliotheca Vincentii Golubovich, ali ime ovog vlasnika naknadno je zamrčeno. Lazarević bilježi (2014:226) da je u dubrovačkoj palači GiorgiBonda 1817. godine živio »violinist Angelo Frezza sa ženom Laurom, kćeri Ružom i zetom Ivanom Golubovićem, troje unuka, i mlađom kćeri Ivanom«. Golubovići su bili s Pelješca, a Ivanov otac zvao se Vicko, isto kao i njegov sin (rođen 1807; vidi Vekarić 1995:241). Više o Angelu Frezza u Demović 1989.

$52 \mathrm{O}$ otkupu zbirke te podrobnije o njezinu sastavu vidi u sljedećim publikacijama: Velikodnaja i Polevščikova 2007; Polevščikova 2010; Polevščikova 2013; Velikodnaja 2015.

${ }^{53}$ Za kratak pregled Jagićeva boravka u Odesi vidi Damjanović 2006:26-27, a za njegova pisma iz tog razdoblja Jagić 1962; 1963; 1970. O Jagićevu odnosu prema Ukrajini vidi Paščenko 2010.

54 Jagić 1876; Maretić 1885. O Maretićevu izdanju Lekcionara i njegovu kasnijem pretisku vidi primjedbe u Lupić 2012:576, bilj. 23.

55 Što se od hrvatskih knjiga nalazi u knjižnici Odeskog sveučilišta, može se pratiti prema već spomenutom katalogu iz devetnaestog stoljeća (Kočubinskij 1878-1884). Tu se između ostaloga spominje (str. 161, br. 193) potpun primjerak prvog izdanja Divkovićeva Nauka krstjanskog (1611, zajedno sa Sto čudesa), koji se ne spominje u najnovijem popisu preživjelih primjeraka ovog Divkovićeva djela (Divković 2013:611630). Navodi taj primjerak u svojoj bibliografiji i Karatajev 1883:320-321, a njegov detaljniji opis donosi Nemirovskij 1992:12 - 13. Taj je primjerak Nauka - izvana obgorio valjda u nekom požaru, ali unutra sasvim dobro očuvan - danas u Odeskoj nacionalnoj znanstvenoj knjižnici. Spomenutom popisu primjeraka Divkovićeva Nauka iz 1611. treba još dodati i primjerak koji je pripadao Josefu Šafaŕíku, a koji se danas čuva 
Izdanje Držićeve Tirene iz 1607. godine tiskano je u osmini. Upotrijebljena su četiri potpuna arka, svaki presavijen triput tako da se dobije osam listova po sveščiću. Sveščići su pri uvezivanju prošiveni po sredini, nakon četvrtog lista. Prva četiri lista svakoga sveščića nose signaturu, za koju se upotrebljavaju slova od A do D uz odgovarajući broj. Iznimka je jedino posljednji sveščić (D) jer u njemu nalazimo deset umjesto osam listova, a prošiven je nakon petog lista. Stoga i signatura teče na prvih pet listova (od D1 do D5). U odeskom primjerku Tirene nije se sačuvala upravo sredina posljednjeg sveščića (listovi D5 i D6, str. 57-60), koja je ionako morala biti tiskana na odvojenom arku. ${ }^{56} \mathrm{U}$ tome se sastoji jedina manjkavost ovog primjerka. ${ }^{57}$

Kada se stanje odeskog primjerka Tirene usporedi sa stanjem Rastićeva rukopisa u Beču, postaje jasno da je Rastiću kao predložak poslužio ovaj tiskani primjerak. U Rastićevu rukopisu nedostaje upravo onaj dio teksta Tirene koji odgovara tekstu na listovima D5-D6. Prijepis se, naime, prekida stihom »I s'kimsam boj bio njesi ti paervi« (list 64r), a nastavlja dva lista kasnije (na dnu 66v) stihom »Tirena ovoje; ah Bosce stoje ovoj? «U Rastićevu se rukopisu ova praznina ni na koji način ne komentira, no naišavši na nju pri sastavljanju svog prijepisa, Kukuljević uime svog predloška bilježi: »ovde faliju dva listovi koji ni su prepisani« (36r). I on zato na tom mjestu ostavlja praznog prostora, a prijepis nastavlja sa stihom koji se podudara s nastavkom teksta u Rastićevu rukopisu. ${ }^{58}$

u Knjižnici Narodnoga muzeja u Pragu pod signaturom 64 F 17. Opisan je u Sokolová 1997:97-98, broj 43. U istoj se knjižnici u Pragu nalazi i primjerak izdanja Divkovićevih Besjeda (1616). Beogradska Narodna biblioteka također ima primjerak Nauka iz 1611. koji treba dodati popisu (začudo, ne spominje ga Nemirovskij, čiji je rad objavljen u Beogradu), a kao dio legata Petra Kolendića u istoj biblioteci nalazi se i jedno očerupano izdanje takozvanog malog Nauka.

56 Tako sudim i zato što je papir listova D5 i D6 u drugim primjercima ovog izdanja grublji nego papir ostatka sveščića.

57 Piesni, uvezane u istom svesku, nemaju naslovnu stranicu (list a1) te list c8 (str. 47-48, početak Novele od Stanca). Kao i u ostalim sačuvanim primjercima Tirene paginacija je poremećena upravo u posljednjem sveščiću (D), i to samo na dva zadnja lista (D9-D10, str. 65-68). Tako umjesto str. 65 nalazimo 41, umjesto 66-67 nalazimo $68-69$, a umjesto 68 nalazimo 36.

${ }^{58}$ Kukuljević krivo prepisuje nadnevak 26. aprila kao 20. aprila, što je dodatna potvrda da mu je predložak bio Rastićev kodeks jer je ondje šestica doista napisana vrlo slično nuli. Odeski primjerak Tirene ima nekoliko ispravaka rukom u tekstu poslanice Aldobrandiniju (vidi Slike 4 i 5), no te ispravke unio je netko nakon Rastića i Stullija. Stulli, međutim, sam primjećuje neke očite pogreške u slogu pa se u prepisivanju popravlja (prvo piše sriegnen, kako je u tisku, a onda to briše pa popravlja u ziegnen). No sličnu pogrešku na sljedećoj stranici (sriennu) dvaput ostavlja neispravljenom pišući srjennu iako je to u tiskanom primjerku ispravljeno rukom. Konačno, malah darak pre- 


\section{Kad ures, kad dike tej zbrajat počnem ja...}

Sada kada znamo da je Vodopijina poslanica kardinalu Aldobrandiniju u Kukuljevićev rukopis stigla iz Rastićeva, a u Rastićev iz odeskog primjerka izdanja Tirene iz 1607, ostaje još otvorenim pitanjem zašto jedno te isto izdanje Tirene postoji u primjercima koji imaju posvetnu poslanicu Vlahu Držiću (sienski i Akademijin), očito polovično tiskanu, naspram primjerka u Odesi koji ima uredno tiskanu posvetnu poslanicu upućenu kardinalu Aldobrandiniju. Jer sigurno je riječ o jednom te istom izdanju s dvije različite poslanice, a nikako o ponovljenom izdanju koje bi bilo pripremano nakon što je već objavljeno izdanje s poslanicom Vlahu Držiću. ${ }^{59}$ Usporedbom otiska u postojećim primjercima izdanja može se ustanoviti da je on u svemu identičan, a da se razlika nalazi samo na jednom listu (A2, str. 3-4), gdje je jedna posvetna poslanica zamijenjena drugom. Dakle, tiskar je upotrijebio iste tiskovne forme (jednu za prednju stranu arka, jednu za stražnju), a u njima je zamijenio samo slog za stranice na kojima je posveta. Odnosno, u slučaju vanjske tiskovne forme, u kojoj se nalazio slog za stranicu A2v, zamjenu nije izvršio kako treba. ${ }^{60}$

pisuje se upravo tako iako je u tiskanom primjerku rukom dodano an (malahan darak). To što Kukuljević ima malahni darak ne znači da on nije prepisivao iz Rastićeva kodeksa, nego samo da je ispravio, kao i na nekoliko drugih mjesta, ono što mu se nije činilo dobro, okrenuvši to $\mathrm{k}$ tome na kajkavski. Pogrešaka u slogu poslanice Aldobrandiniju ima dobar broj, a one su takve prirode da ili slagar nije baš razumio ono što slaže ili je bio vrlo nemaran.

${ }^{59}$ Usp. Držić 1930:XXVI.

60 Bibliografska terminologija na engleskom jeziku razlikuje pojmove edition, impression, issue i state. Ovdje je riječ o istom izdanju (edition) koje je istovremeno objavljeno u dva različita oblika (issue) u kojima se jedino razlikuju posvetne poslanice. $\mathrm{Ne}$ čini mi se najsretnijim rješenje da se na hrvatskom za ono što ja zovem oblik izdanja (issue) upotrebljava termin novi otisak jer otisak (impression) nije novi, nego je - dakako izuzev stranica o kojima je ovdje riječ - izvršen iz istog sloga $u$ isto vrijeme; usp. Katić 2007:46 - 47. To je jasno i po tome što kvaliteta papira u svim primjercima izdanja iz 1607. varira na sličan način, odnosno u sveščićima b, c i d (Pjesni) papir postaje svjetliji i tanji. O novom otisku moglo bi se govoriti kada bi se slog za čitavu knjigu sačuvao, a onda se nakon prvog izdanja ponovno otisnulo iz istog sloga još primjeraka, bilo iste godine bilo kasnije. No dok je to čest slučaj od devetnaestog stoljeća naovamo, za rukom slagani tekst to bi bilo izrazito nepraktično jer je tiskar ograničen brojem slova koja su mu na raspolaganju. Zato se slog iz formi iz kojih je već tiskano obično odmah raspoređuje natrag u pismovni ormar kako bi poslužio za daljnje slaganje teksta, što se može lijepo vidjeti kada se iste ilustracije ili na isti način oštećena slova javljaju unutar iste knjige no unutar različitih tiskovnih formi (dobar primjer je ukras na kraju drugog izdanja Tirene, D8v, koji je onda - sigurno iz istog drvoreza tiskan na početku Pjesni, a2v). Novi oblici istog izdanja mogu biti objavljeni i nekoliko godina nakon prvog izdanja, samo što se nerasprodanim primjercima zamijeni naslovna stranica ili prvi sveščić (s predgovorom ili sličnim materijalima: za zanimljive 
Taj bi nam neobični propust, međutim, mogao pomoći da odgovorimo na pitanje kojim su redoslijedom dvije posvetne poslanice tiskane. Primjerak u Nacionalnoj i sveučilišnoj knjižnici u Zagrebu mora se isključiti iz analize jer njemu nedostaju i prvi i drugi list, a time i posvete o kojima je ovdje riječ. Odeski primjerak sadrži posvetu Aldobrandiniju, a sienski i onaj Akademijin u Zagrebu sadrže nepotpuno otisnutu posvetu Vlahu Držiću. Usporedba kvalitete tiska u prvom arku tih primjeraka pokazuje kvalitetniji otisak u odeskom primjerku, a osobito se to vidi u otisku pojedinih slova, koja su se očito tijekom tiskanja pomaknula ili razlabavila, što je rezultiralo slabijom kvalitetom. ${ }^{61}$ Nadalje, u poslanici Aldobrandiniju za glas $/ \mathrm{k} /$ ispočetka je upotrebljavano obično slovo, da bi tog slova prema kraju poslanice slagaru očito ponestalo u pismovnom ormaru, te njega nadalje zamjenjuje kurzivnim $k$ iako ostatak sloga nije u kurzivu. Za razliku od toga, u poslanici Vlahu Držiću, slovo $k$ je svuda kurzivno u protivnosti prema svim drugim slovima, koja nisu u kurzivu. ${ }^{62}$ Sve to na-

primjere takvih oblika istog izdanja, a ne u strogom smislu novih izdanja malog $\mathrm{Na}$ uka Matije Divkovića te Naslađenja duhovnog Pavla Posilovića, vidi Rešetar 1916:467). Kao što ću pokazati ispod (vidi bilješku 67), u drugom izdanju Tirene nalazimo i različita tiskana stanja (state) jer je unutar sloga za prvi arak tijekom tiskanja uočena, a zatim i popravljena jedna doista neznatna pogreška, što je rezultiralo primjercima koji sadrže različita čitanja.

${ }^{61}$ Tako na listu A6v (str. 12) u sienskom primjerku u stihu koji počinje riječima »Tac suakom milofti « slovo o u suakom toliko je slabo otisnuto da se skoro i ne vidi. U sienskom primjerku Ia niefam (A8v, str. 16) otisnuto je a niefam, dok je u odeskom primjerku otisak uredan.

62 Talijanskim tiskarima slovo $k$ inače nije trebalo ni za talijanski ni za latinski, a često ga upravo zato ne nalazimo $\mathrm{u}$ hrvatskim knjigama tiskanima $\mathrm{u}$ Italiji. Kako Bariletti tekst Držićevih djela tiska u kurzivu, morao je imati više kurzivnog $k$ u pismovnom ormaru. Slično su se ovom problemu dovijali talijanski tiskari i prije Barilettija: vidi, na primjer, kako je tiskano slovo $k$ u posvetnoj poslanici koju Dinko Ranjina prilaže izdanju svojih pjesama (Pjesni razlike, 1563), a onda to usporedi s obrnutim primjerom koji ilustrira istu nevolju u posvetnoj poslanici koju Dominko Zlatarić prilaže izdanju svojih djela (Elektra i dr., 1597). Zlatarićeva knjiga izašla je s različitim naslovnim stranicama (1597. i 1598), kako javlja Stipčević (2012; 2013), koji zaslužuje pohvalu jer je u knjižnici Državnog arhiva u Zadru locirao primjerak Zlatarićeva Ljubmira iz 1580. Dotad nam je jedini siguran svjedok o postojanju tog izdanja bio prijepis Đura Ferića (Arhiv Male braće, Dubrovnik, rukopis 122; usp. Lupić 2012:903, bilj. 49; 928, bilj. 80; Lupić 2014:47, bilj. 29). No s oprezom treba pristupati onome što Stipčević javlja o sačuvanim primjercima Zlatarićevih djela izdanih u Alda 1597/1598. Ne postoji primjerak za koji Stipčević tvrdi da je u Kaliforniji (UCLA) jer se navodi u katalogu ondašnje poznate zbirke Aldovih izdanja. On je tu krivo razumio katalog, u kojem se naime navode i Aldova izdanja od kojih se u toj zbirci ne nalazi primjerak. Poznatim primjercima iz HAZU i Austrijske nacionalne knjižnice Stipčević dodaje još samo milanski primjerak (Braidense). No taj primjerak za koji nam Stipčević kaže da ga je »otkrio« u Milanu poznat je bio još Kukuljeviću, koji o njegovu postojanju javlja u Danici ilirskoj iz 
vodi na pomisao da je poslanica Aldobrandiniju složena i tiskana prva, a moguće je da je tiskana u manje primjeraka, jedan od kojih je svakako bio namijenjen Aldobrandiniju. Takva praksa nije strana ranonovovjekovnom izdavaštvu. ${ }^{63}$

To bi imalo smisla jer se onda može lakše razumjeti činjenica da je posveta Aldobrandiniju tiskana u cijelosti, dok je posveta Vlahu Držiću otisnuta samo polovično. Razmotrimo na trenutak tiskovne forme za izdanje u osmini (Slika 6) te raspored stranica sloga vanjske forme (za otisak na jednoj strani arka) naspram unutarnje forme (za otisak na drugoj strani arka). ${ }^{64}$ Važno je primijetiti da sve stranice otisnute na jednoj strani arka nisu, nakon što se arak presavije za uvez, ujedno i na istoj strani listova. Tako su A1r i A2v u istoj, vanjskoj tiskovnoj formi iako se A1r nalazi na prednjoj, a A2v na stražnjoj strani lista u tiskanoj knjizi. Može se pretpostaviti da su tiskovne forme za arak $\mathrm{A} u$ prvom obliku, s poslanicom Aldobrandiniju, bile potpune. Nakon što su iz njih, međutim, izvađene dvije stranice sloga (A2r i A2v), koje pripadaju dvjema različitim tiskovnim formama, na njihovo mjesto trebale su biti stavljene dvije stranice sloga s posvetom Vlahu Držiću. Kako čak u dva primjerka nalazimo jednu od dvije stranice praznu (A2v), tu se morao dogoditi propust koji nije odmah zamijećen.

Moja je pretpostavka da taj propust ima veze s činjenicom da je u vanjskoj tiskovnoj formi, u kojoj se nalazi A2v, jedna stranica već morala ostati prazna. To je, naime, naslovna stranica (A1r), koja je otisnuta na drugoj vrsti stroja nakon što su na prvom stroju otisnuta slova. To se moralo napraviti zato što je naslovna stranica u bakrorezu, za čiji je otisak potreban veći pritisak, a onda i drugačiji tiskarski stroj. ${ }^{65}$ Takva se pretpostavka, konačno, slaže s tiskarskom praksom prema kojoj se otisak prvo vrši s unutarnje tiskovne forme (u kojoj je A2r), a onda svaki arak ponovno prolazi kroz prešu kako bi se izvršio otisak s vanjske tiskovne forme (na kojoj su na-

1841. (usp. Jakić 1962:149, bilj. 13). Taj je primjerak bio poznat i najutjecajnijem proučavatelju Aldovih izdanja u devetnaestom stoljeću (vidi Renouard 1834:254), koji k tome spominje još tri primjerka: jedan u Bodleian Library, Oxford, jedan u vlasništvu lorda Spencera i jedan u vlasništvu grofa Méjana. Oxfordski primjerak (1598) još uvijek je ondje gdje je i bio; Spencerov (1597) je danas u John Rylands Library u Manchesteru; Méjanov (1598) u Staatsbibliothek zu Berlin.

${ }^{63} \mathrm{O}$ tome vidi $\mathrm{u}$ Williams 1952 te, za iscrpan popis takvih primjera $\mathrm{u}$ ranonovovjekovnom engleskom tisku, Williams 1962:240 - 256.

64 Slika je preuzeta iz Gaskell 1972:92. Gaskell prednju i stražnju stranu lista bilježi sa $a$ i $b$, dakle $\mathrm{A} 1^{\mathrm{a}}$ za A1r, A1 ${ }^{\mathrm{b}}$ za A1v i tako dalje. Vanjska je forma outer forme, unutarnja je inner forme.

${ }^{65}$ Gaskell 1972:156-159. 
slovnica i A2v). ${ }^{66}$ Drugim riječima, propust se dogodio u drugom koraku, vezanom uz zamjenu stranice sloga u vanjskoj tiskovnoj formi (za A2v), u kojoj je jedna stranica ionako bila bez sloga (A1r) jer je za nju predviđena naslovnica u bakrorezu. Dok se ne nađe neki novi primjerak izdanja Tirene iz 1607. s potpunom posvetnom poslanicom Vlahu Držiću, moramo zaključiti da je ovaj propust, koliko god velik, ostao neispravljen kroz većinu tiraža. ${ }^{67}$

Različite posvetne poslanice unutar istog izdanja u ranoj tiskanoj knjizi nisu, zanimljivo je, rijetkost. Premda ih ovdje nalazimo u izdanju nakon Držićeve smrti, one su svejedno važne jer nam govore o tome kome su sve hrvatske knjige bile namijenjene i kako su se sve Dubrovčani nastojali još više umiliti onima u čijoj su milosti bili. Kako piše Vodopija, premda je slovinski jezik nadaleko cijenjen, njegovo »običajno dostojanstvo« uvećano je time što ga je Aldobrandini, po naputku svoga dunda, pape Klementa VIII, primio, naučio i, ako je Vodopiji vjerovati, njime »kako istijem materinijem « govorio. ${ }^{68}$ Upravo zato Vodopija »ovu pripovijes pastijersku« daje

\footnotetext{
${ }^{66}$ Gaskell 1972:127. Ispitivanjem svih primjeraka izdanja Tirene iz 1607. mogao sam ustanoviti da je unutarnja tiskovna forma uistinu kroz prešu prolazila prva. Naime, na onoj strani arka koja je tiskana prva nalaze se ispupčenja zbog pritiska slova s druge strane pri ponovnom prolasku arka kroz prešu. Ispupčenja se u tiskanim primjercima Tirene uvijek nalaze na stranicama koje pripadaju unutarnjoj formi. Obraćajući pozornost na papir, osobito na grudvice smjese koje se obično nalaze prema krajevima arka, mogao sam ustanoviti da su krajevi arka desni rubovi stranica A1r, A2r, A3r itd. Time se dodatno potvrđuje pretpostavka da su stranice sloga raspoređene $u$ obični osminski format, a ne u takozvanu obrnutu osminu, koja je bila česta u knjigama tiskanima u Italiji u ovo vrijeme; usp. Cook 1957.

${ }^{67}$ Bakrorezne naslovnice ponekad su se tiskale na odvojenom listu, a onda bi bile ulijepljene s ostatkom izdanja. No to ovdje ne može biti slučaj jer je na istom listu na kojem je otisnut bakrorez na drugoj strani otisnut popis likova u Tireni. Zanimljivo je da je tijekom tiskanja prvog arka zamijećena pogreška u kustodi na A3r. Tu odeski primjerak, za koji ja mislim da je tiskan prvi, ima kustodu karui bez zareza, dok sienski i Akademijin primjerak imaju ispravljenu kustodu karui, (dakle sa zarezom; usp. kustodu na A4v i kasnije, u Pjesnima, na a2r, gdje se vidi da se zarez smatra dijelom kustode). Iako je ovaj ispravak nevažan za tekst, on je važan jer ga nalazimo provedenog u četvrtom poznatom primjerku Tirene i Pjesni, onom krnjem u NSK u Zagrebu, gdje je prvi sačuvani list upravo A3. To ovaj primjerak stavlja u istu skupinu sa sienskim i Akademijinim. Stoga se može pretpostaviti da je i u njemu bila tiskana poslanica Vlahu Držiću, a ne Aldobrandiniju. Naime, zamjena sloga za tekst poslanice ujedno je idealna prilika da se provedu i manje izmjene ove vrste (u toj se izmjeni slog za A3r malo poremetio, što se vidi u neznatno promijenjenom položaju ukrasnog inicijala u odnosu na prvi redak teksta). Tako bi, dakle, od svih preživjelih primjeraka upravo odeski primjerak Tirene bio jedini primjerak onog oblika izdanja koji sadržava poslanicu Aldobrandiniju.

${ }^{68}$ Govoreći o slavi ilirskoga jezika u stranom svijetu, Kukuljević kaže sljedeće o Aldobrandiniju: »Isto tako cěnio je ilirski jezik papa Klemens VIII., bivši kao kardinal pa-
} 
»iznova na svitlos«, pokazujući time zahvalnost za učinjeno dobročinstvo: kada je već, naučivši ga, uvećao čast slovinskoga jezika, Aldobrandini zaslužuje da mu se daruje jedan istaknut primjer umjetničkog dosega tog jezika. Iako već skoro četiri godine kardinal, Aldobrandini je tada imao svega dvadeset godina, a umro je pet godina nakon izdanja Tirene. ${ }^{69}$

Ostaje nejasno tko je sastavio drugu, polovično tiskanu posvetnu poslanicu u izdanju Tirene i Pjesni iz 1607, upućenu Vlahu Držiću. Rešetar je smatrao da je tu štamparovu posvetu, kako je on zove, pisao »neko u Mlecima, i to neko što je mjesto $s v-u$ početku riječi izgovarao, pa zato i pisao $s f-$, čega inače u Držića nikako nema «, ali takvo dokazivanje nije utemeljeno. ${ }^{70}$ Vezu sf-nalazimo često u dubrovačkim rukopisima. ${ }^{71}$ Svejedno, iz sadržaja poslanice, koja ima osobine dubrovačkog govora, doista proizlazi da ju je pisao ili dao prevesti netko tko nije bio Dubrovčanin. On spominje »jezik dubrovački«, a o Dubrovčanima govori u trećem licu, kao o »onomu slavnomu narodu « kojemu on ovim novim izdanjem želi iskazati svoje poštovanje. Budući da je prvo izdanje razgrabljeno i da je još mnogo onih koji bi Tirenu željeli čitati, odlučio je on nju, kako kaže, »drugi put na dvor izvesti, u oni bolji način kako sam mogo i kako mi je brijeme dopustilo, ne ostavivši nazada truda kim sam je urešeniju mogo učiniti«. Da truda uistinu nije žalio, vidi se po tome što je ilustrirana naslovnica izrađena u bakrorezu, i to isključivo za ovo izdanje..$^{72}$ Tko god se krio iza ovog hvale vrijed-

pinski legat u Poljskoj. On je dao i svoje netjake Franju i Silvestra Aldobrandinia podučavati temeljito u jeziku ilirskom od njihovog učitelja Nikole Brautića « (Kukuljević 1846:78). Tu Kukuljević zatim spominje posvetu Tireni iz 1607. godine. Appendini piše (1802-1803, II:135-136) da je Klement VIII. tražio nadarenog učitelja za svog nećaka Francesca, pa da mu je preporučen Lopuđanin Nikola Brautić (1566-1632), a Silvestra ne spominje. Silvestar je bio sin Francescov, dakle Klementov pronipote, kako piše Körbler (1912:14), koji pak dalje kaže (slijedeći vijesti Serafina Marije Crijevića) da je papa tražio učitelja za sina svoga nećaka Francesca, dakle za Silvestra, te da se to vjerojatno događalo oko 1595. godine. Ako je vjerovati Körbleru, sa svega dvanaest godina (1599) Silvestro Aldobrandini piše papinskom nunciju u Mlecima kako bi se zauzeo za nekakav beneficij koji je Brautić dobio u Trogiru (1912:15). Brautić nije kasnije imao osobito dobre odnose s familijom Aldobrandini. Ginammi je objavio Brautićev Martyrologium poeticum iste godine kad i treće izdanje Tirene (1630).

69 Osnovne vijesti o Silvestru Aldobrandiniju (1587-1612) donosi Cardella 1793:85-86; vidi također odgovarajuću natuknicu u Novak et al. 2009.

70 Držić 1930:XXI, 66.

${ }^{71}$ Lupić 2012:573-579. Od objavljivanja tog rada naišao sam u dubrovačkim rukopisima na toliko primjera pisanja $s f$ - da se doista čudim Rešetarovoj primjedbi, da o braniteljima te primjedbe i ne govorim. Rešetar, doduše, kaže da toga nema u Držića, ali predmet mu je rasprave tekst pisan na početku sedamnaestog stoljeća.

72 Usp. Gaskell 1972:158-159 o troškovima vezanima uz tiskanje ilustracija u bakrorezu. U natuknici »Grafika« u Leksikonu Marina Držića (Novak et al. 2009) Milan Pelc opisuje ovu ilustriranu naslovnu stranicu kao bakropis (etching); ja mislim da je 
nog i poprilično skupog truda, jasno je da je on Tirenu i Pjesni smatrao jednom knjigom ne samo u ovom izdanju nego i u izdanju iz 1551, jer to izdanje opisuje riječima »Tirena komedija s razlicijem pjesni i druzim lijepim stvarmi«. U tome je on svakako bio u pravu, ali to pitanje zavređuje da se o njemu raspravlja odvojeno.

\footnotetext{
ipak riječ o bakrorezu (engraving). Bakrorezac se potpisuje kao Gasparo Grispoldo, a u priručnicima mu se ime navodi i kao Gaspare Grispoldi. Pelc ispravno primjećuje da je naslovnica rađena isključivo za ovo izdanje pa se stoga može tumačiti u izravnoj vezi s Držićevim tekstom. I tu bi, međutim, trebalo prvo istražiti kakvi su bakrorezi inače rađeni za Barilettijeva izdanja te ima li među njima sličnosti. S druge strane, prikaz zemaljske kugle koji nalazimo na naslovnom listu Držićevih Pjesni iz 1607. ne može se dovoditi u isključivu vezu s Držićem jer je riječ o Barilettijevu standardnom tipografskom i knjižarskom znaku (alla insegna del mondo; sub signo mundi), a on se javlja i u drugim izdanjima. Tako ga nalazimo upotrijebljena u knjizi jednog drugog Dubrovčanina koju je Bariletti objavio još 1598: Antonii Medi Ragusini in librum duodecimum metaphysicae Aristotelis expositio. Za dobar primjer naknadnog otiska zemaljske kugle na već tiskanu naslovnicu vidi Barilettijevo izdanje L'Epistole d'Ovidio (1604). Upravo je dakle iz trgovačkih, a ne umjetničkih pobuda u bakrorez za naslovnicu Tirene uključen globus u donjem dijelu stranice.
} 
Ivan Lupić: Posvetne poslanice u drugom izdanju Držićeve Tirene (1607) FILOLOGIJA 67(2016), 65-98

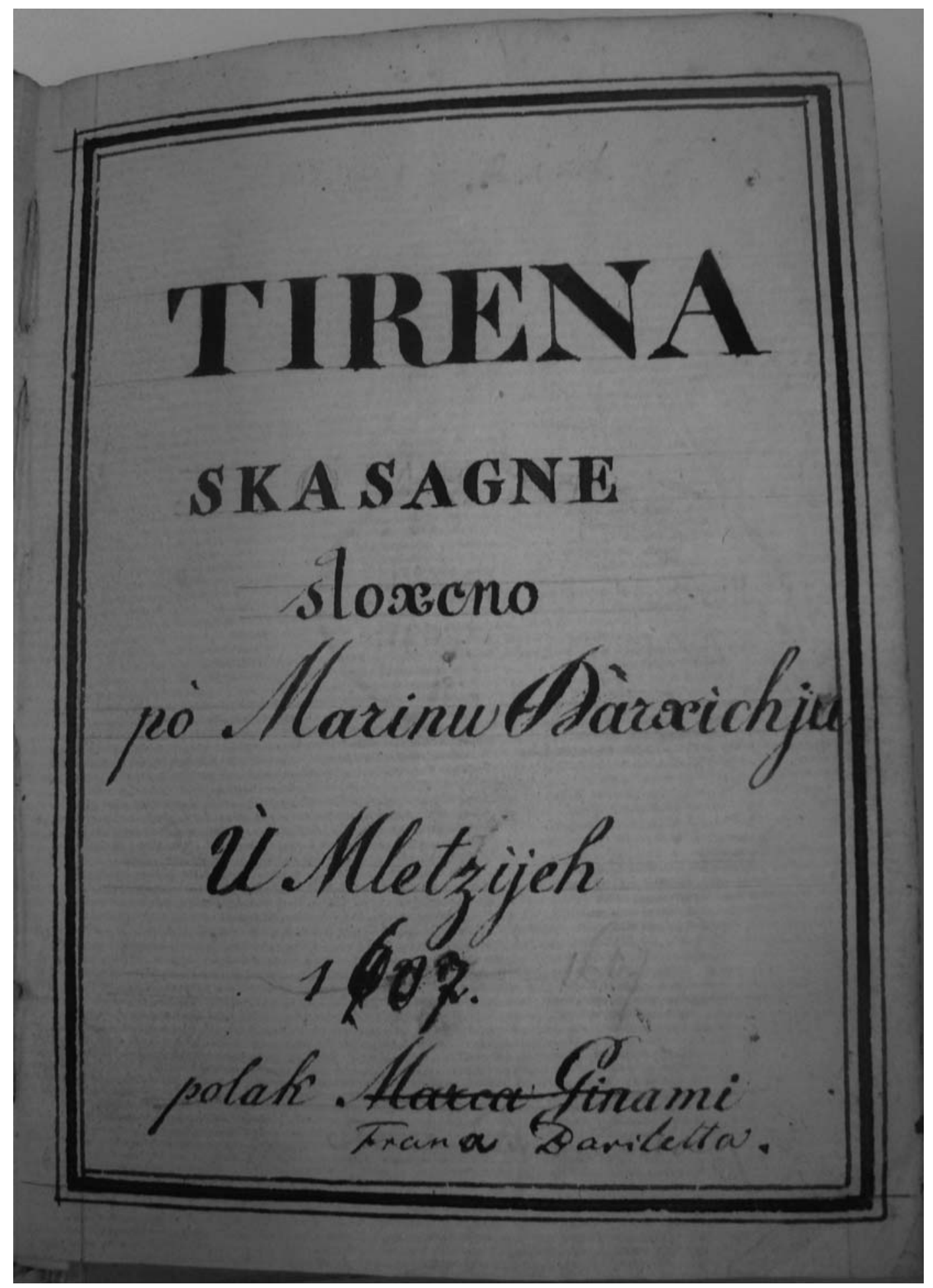

Slika 1: Zamjenska naslovnica u Akademijinu primjerku drugog izdanja Tirene (1607). 


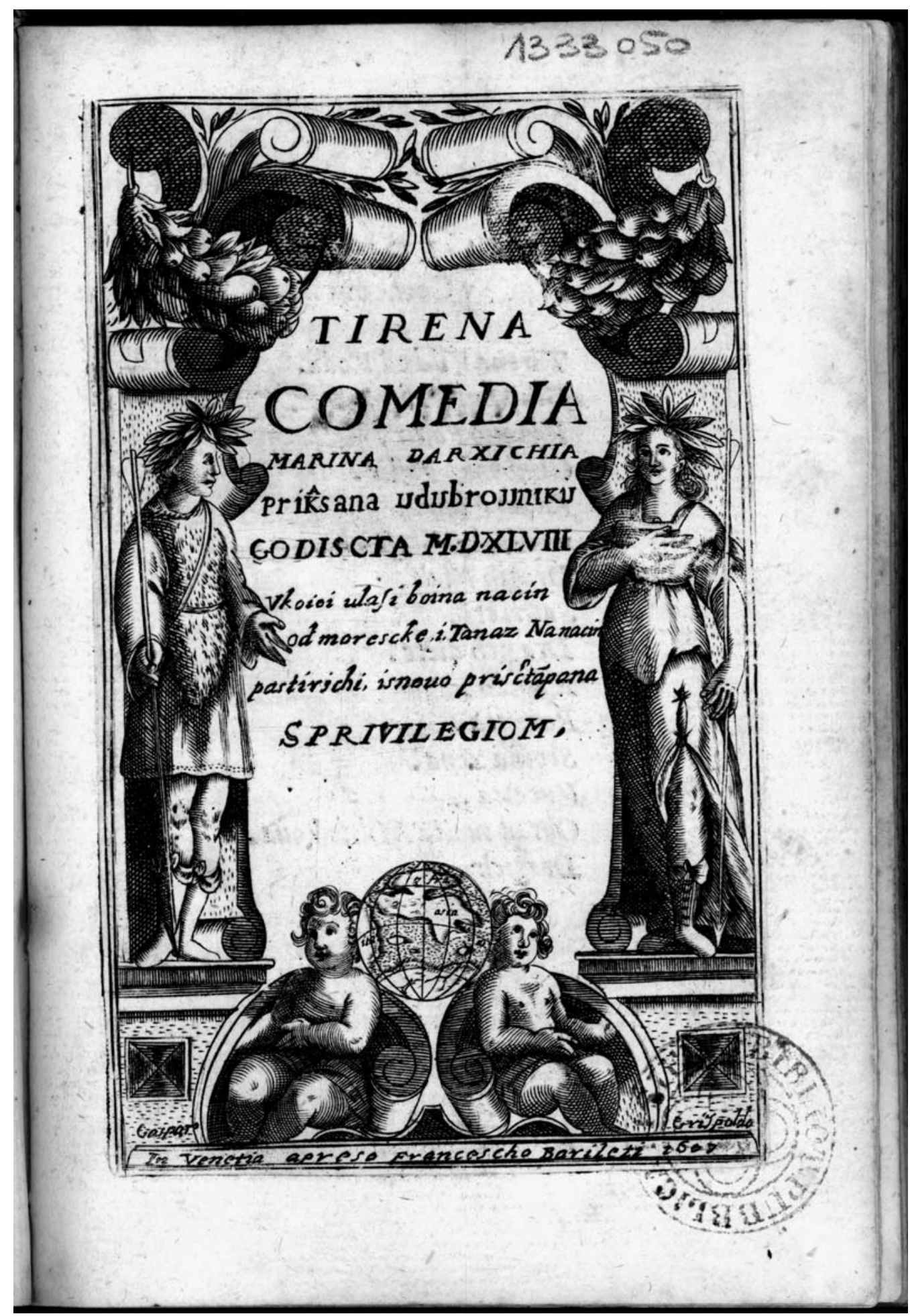

(

Slika 2: Naslovni list sienskog primjerka drugog izdanja Tirene (1607). 
Ivan Lupić: Posvetne poslanice u drugom izdanju Držićeve Tirene (1607) FILOLOGIJA 67(2016), 65-98

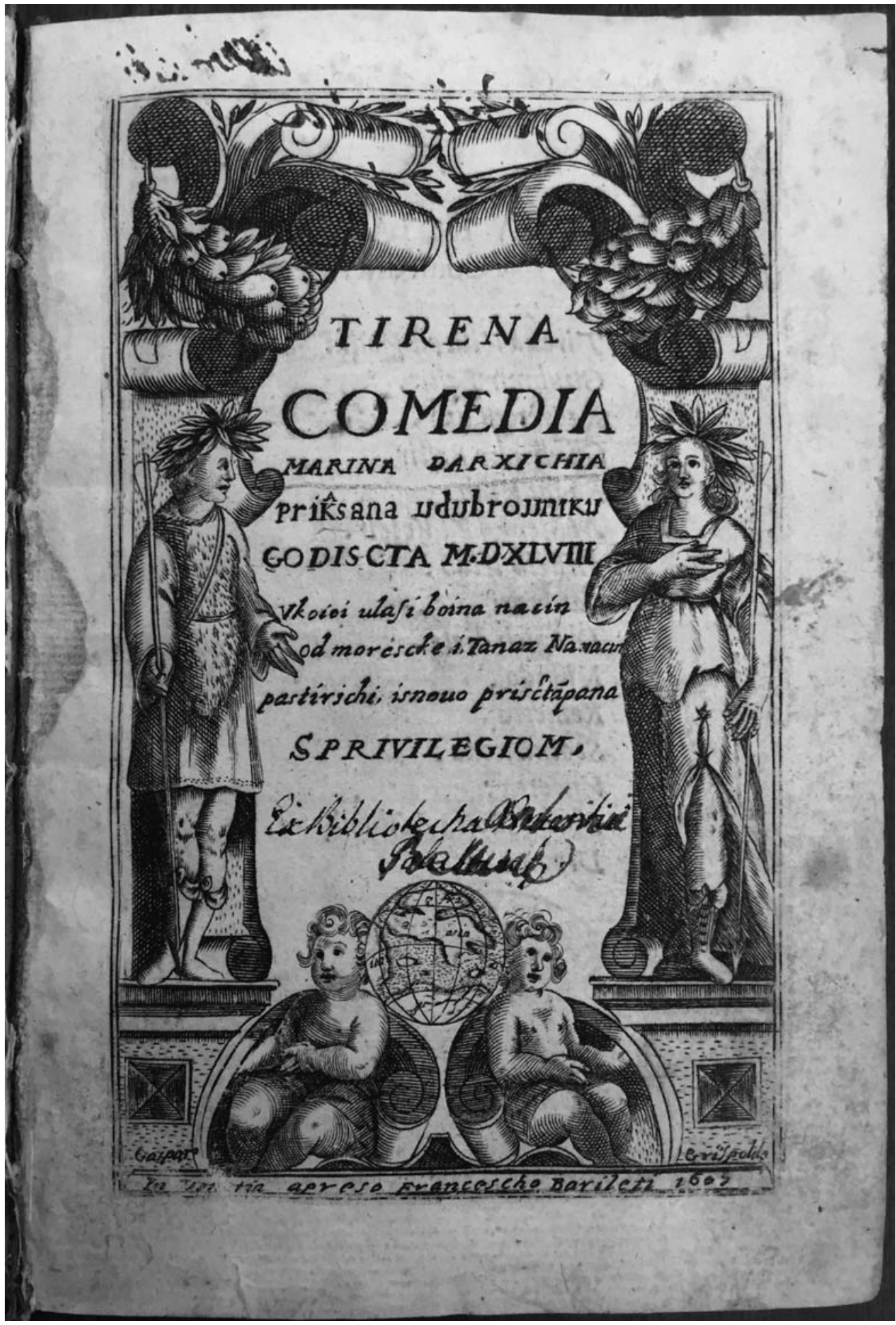

$(\varphi$

Slika 3: Naslovni list odeskog primjerka drugog izdanja Tirene (1607). 


\section{PRISVIT LOMV, I PRIPOSTOVANOMV}

Gofpodinu, i Gofpodaru moiemu,

\section{GOSPOD. SILVESTRV.}

\section{A L D OB R A D I N V}

\section{CARD. CESAREV.}

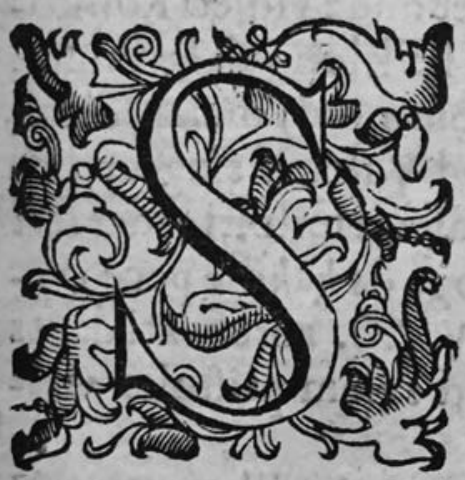

A sueda Slovinski iefik Prisvitli Gofpodaru ù Velikoi ciafti, i doftoianftrr pofebbi nahodi fe, i mavfci mnoghe ne pridobi te Kraglieve, $i$ Golpodu,koijgnim na ravno govore, iprofti rucchife vele vecchiedielu odEurope, nisctanemagne vidife fada ocit to da gnegovo obiciaino doitoianftro neifmernu sziernnu, i cias dobiloie ; buduchife ganulo V.P.G. ponaredbi Svetogo Ozza Papx Clemenmenta V II I. ceftite vspomene, dunda Vafcega, receni iefik primiti, nauciti, i gnim kakoiftiem materiniem govoriti : koia ftuar vcinilaie dare ceni iefik fadafe nahodi ù vafcemu bitiu, i hijpu toliko sriegnen, koliko iedan draghi kami vfa

$$
\text { A 2. ghien }
$$

Slika 4: Početak posvete Silvestru Aldobrandiniju u odeskom primjerku drugog izdanja Tirene (1607). 




Slika 5: Nastavak posvete Silvestru Aldobrandiniju u odeskom primjerku drugog izdanja Tirene (1607). 

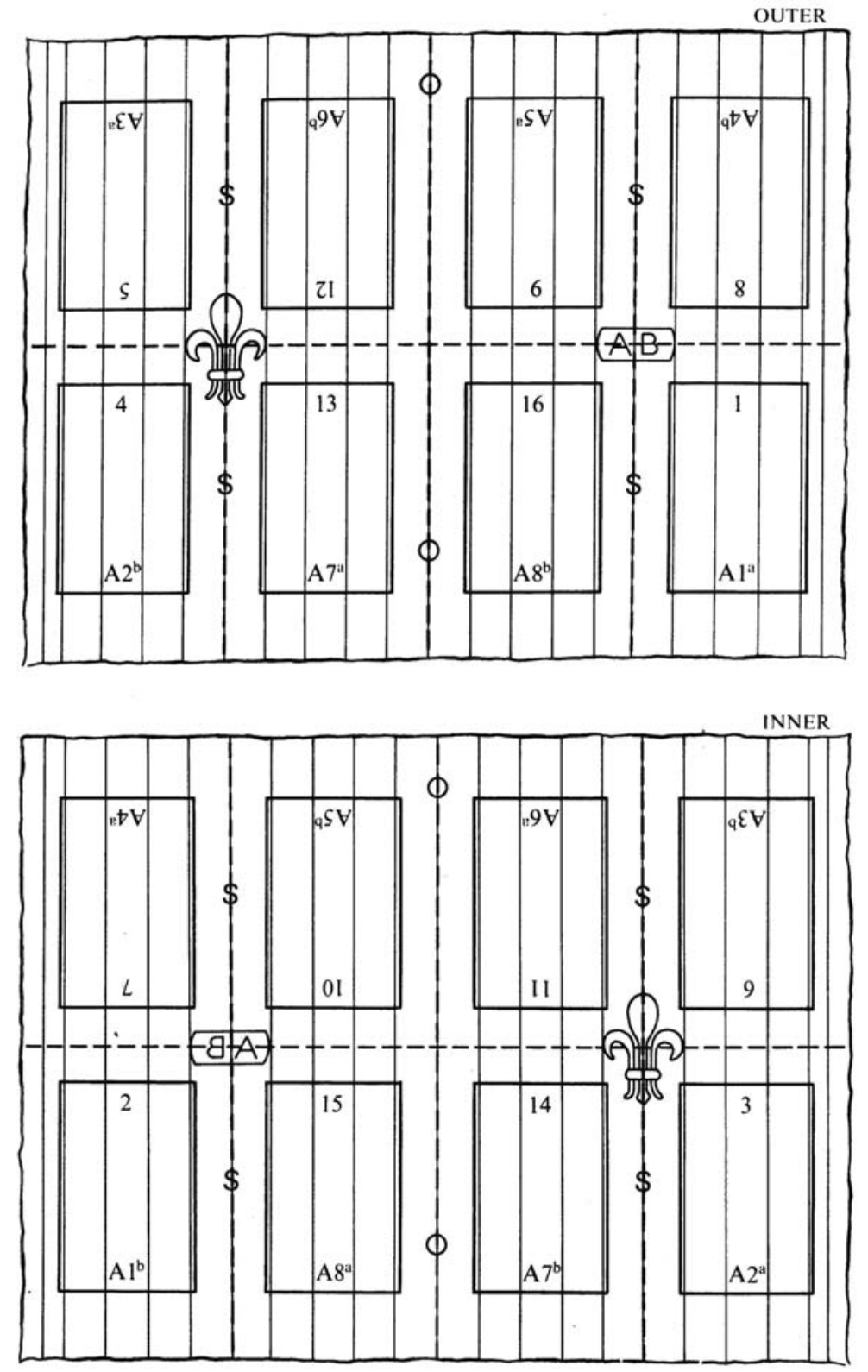

FIG. 50. Sheet of common octavo $\left(8^{\circ}\right)$; see note C, p. 106 .

Slika 6: Raspored stranica unutar tiskovnih formi za obični osminski format (Gaskell 1972:92). 


\section{Literatura}

Appendini, Francesco Maria. 1802-1803. Notizie istorico-critiche sulle antichità, storia e letteratura de' Ragusei. 2 sv. Ragusa: Antonio Martecchini.

Bratičević, Irena i Ivan Lupić. 2013. Držićeva Hekuba između izvedbe i knjige. »Colloquia Maruliana«, 22:77-116.

Brlek, Mijo. 1987. Leksikograf Joakim Stulli. Zagreb: JAZU.

Cardella, Lorenzo. 1793. Memorie storiche de' cardinali della Santa romana chiesa. Tomo sesto. Roma: Pagliarini.

Cook, D. F. 1957. Inverted Imposition. »The Library«, 5th series, 12.3:193196.

Damjanović, Stjepan. 2006. Opširnost bez površnosti: podsjetnik na život i djelo Vatroslava Jagića. Drugo, izmijenjeno i dopunjeno izdanje. Zagreb: $\mathrm{Hr}-$ vatska sveučilišna naklada.

Della Bella, Ardelio. 1785. Dizionario italiano-latino-illirico. 2 sv. Ragusa: Nella Stamperia Privilegiata.

Demović, Miho. 1989. Glazba i glazbenici u Dubrovačkoj Republici od polovine XVII. do proog desetljeća XIX. stoljeća. Zagreb: JAZU.

Divković, Matija. 2013. Nauk krstjanski za narod slovinski - Sto čudesa aliti zlamen'ja blažene i slavne Bogorodice, divice Marije. Ur. Darija Gabrić-Bagarić, Dolores Grmača, Maja Banožić, Marijana Horvat. Sarajevo: Kulturno-povijesni institut Bosne Srebrene.

Držić, Marin. 1874. Djela. [Priredio Franjo Petračić.] Stari pisci hrvatski, VII. Zagreb: JAZU.

Držić, Marin. 1930. Djela. Drugo izdańe (sa dvije table). Za štampu priredio Milan Rešetar. Stari pisci hrvatski, VII. Zagreb: JAZU.

Držić, Marin. 1989. Piesni ujedno stavljene s mnozim druzim liepim stvarmi. Pretisak. [Napomena uz pretisak: Slobodan Prosperov Novak.] Zagreb: Sveučilišna naklada Liber.

Držić, Marin. 2008a. Tirena 1551. Faksimilni pretisak. Pogovor Ennio Stipčević. Biblioteka Starine, 3. Zagreb: Školska knjiga.

Držić, Marin. 2008b. Pjesni ljuvene 1551. Faksimilni pretisak. Pogovor Ennio Stipčević. Biblioteka Starine, 4. Zagreb: Školska knjiga.

Gaskell, Philip. 1972. A New Introduction to Bibliography. Oxford: Clarendon Press.

Jagić, Vatroslav. 1876. Zwei bibliographische Seltenheiten. »Archiv für slavische Philologie«, 2:720-726.

Jagić, Vatroslav. 1962. Aus Vatroslav Jagić's Briefwechsel: Odessa - Berlin Petersburg, 1872-1892. Ur. Hubert Rösel. München: Verlag Otto Sagner.

Jagić, Vatroslav. 1963. Письма И. В. Ягича к русским ученым, 1865-1886. 
Издание подготовиди Г. П. Бдок и Т. И. Иысенко. Под. ред. В. В. Виноградова и Г. П. Блока. Москва - Денинград: Издательство Академии наук СССР.

Jagić, Vatroslav. 1970. Korespondencija Vatroslava Jagića. Knjiga 2: Pisma iz Rusije, 1865-1886. Ur. Josip Hamm. Zagreb: JAZU.

Jakić, Tomislav. 1962. O postanku i sastavu biblioteke Ivana Kukuljevića. »Rad JAZU«, 324:145-170.

Karatajev, Ivan. 1883. И. Каратаев. Описаніе славяно-русскихъ книгъ, напечатанныхъ кирилловскими буквами: съ 1491 по 1652 г. Сборникъ отдБленія русскаго языка и словесности Императорской Академіи Наукъ. Томъ XXXIV, № 2. Санктпетербургъ: Типографія Императорской Академіи Наукъ.

Katić, Tinka. 2007. Stara knjiga: bibliografska organizacija informacija. Zagreb: Hrvatsko knjižničarsko društvo.

Kočubinskij, Aleksandr Aleksandrovič. 1878-1884. А. А. Кочубинскій. Каталогъ Библіотеки Императорскаго новороссйскаго университета. Томъ І. Одесса: Типографія П. А. Зеленаго.

Kolendić, Anton. 1956. Prvo izdanje Gundulićevih Suza. »Pitanja književnosti i jezika«, 3:113-120.

Kožičić, Šimun. 1984. Knjižice krsta. Priredila Anica Nazor. Ljubljana - Zagreb: Cankarjeva založba.

Körbler, Đuro. 1912. Život i književni rad biskupa Nikole Brautića Lopuđanina (1566-1632). »Rad JAZU«, 192:1-96.

Kukuljević Sakcinski, Ivan. 1846. Flora Zuzorić: čàrtica iz historie ilirske književnosti XVI. věka. »Danica horvatska, slavonska i dalmatinska«, 12.20:77-78.

Kukuljević Sakcinski, Ivan 1858. Stari pjesnici hrvatski, Svezak II: Pjesnici hrvatski XVI stoljetja [omot]. Pjesnici hrvatski XVI. vieka: Razdjel proi [naslovni list]. Zagreb: Tiskom Nar. tiskarne Dra. Ljudevita Gaja.

Kukuljević Sakcinski, Ivan. 1860. Bibliografia hrvatska. Dio prvi: Tiskane knjige. Zagreb: Brzotiskom Dragutina Albrechta.

Kukuljević Sakcinski, Ivan. 1867. Jugoslavenska knjižnica Ivana Kukuljevića Sakcinskoga. Zagreb: Knjigotiskarna Dragutina Albrechta.

Lazarević, Ivana. 2014. Vlasteoske kuće u gradu Dubrovniku 1817. godine. Zagreb - Dubrovnik: Zavod za povijesne znanosti HAZU.

Lupić, Ivan. 2010. Nove teorije i stare knjige. »Forum«, 49:1192-1238.

Lupić, Ivan. 2012. Tekstološka načela, kritička izdanja i kroatistička znanstvena zajednica. »Forum«, 51:557-589; 895-958.

Lupić, Ivan. 2014. Piligrinov otpor. Otpor: subverzione prakse u hrvatskome jeziku, književnosti i kulturi. Ur. Tatjana Pišković i Tvrtko Vuković. Za- 
greb: Zagrebačka slavistička škola; 35-79.

Maretić, Tomo, ur. 1885. Lekcionarij Bernardina Spljećanina. Po prvom izdanju od god. 1495. Zagreb: JAZU.

Marulić, Marko. 1869. Pjesme. Skupio Ivan Kukuljević Sakcinski. [Priredio Vatroslav Jagić.] Stari pisci hrvatski, I. Zagreb: JAZU.

Martinović, Sonja. 2009. Marin Držić: Bibliografija i literatura. Zagreb: Nacionalna i sveučilišna knjižnica; Leksikografski zavod Miroslav Krleža.

Morović, Hrvoje. 1971. Povijest biblioteka u gradu Splitu. Dio I. Zagreb: Društvo bibliotekara Hrvatske.

Muhoberac, Mira. 2008. Tko je nama Držić? »Vijenac«, 16.381 (9. X. 2008): 10.

Napoli, Maria C. 1990. L'impresa del libro nell'Italia del seicento: La bottega di Marco Ginammi. Napoli: Guida editori.

Nemirovskij, EvgenijLjvovič. 1992. Е. А.Немировский. Южнославянские кирилловские издания в Оддесской государственной научной библиотеке имени М. Горького. »Arheografski prilozi«, 14:7-14.

Novak, Slobodan P., Milovan Tatarin, Mirjana Mataija i Leo Rafolt, ur. 2009. Leksikon Marina Držića. Zagreb: Leksikografski zavod Miroslav Krleža.

Paščenko, Jevgenij. 2010. Slavist $i$ imperiji: Vatroslav Jagić između Galicije, Malorusije i Ukrajine. Predgovor Stjepan Damjanović. Zagreb: Hrvatsko-ukrajinsko društvo.

Polevščikova, Elena Viktorovna. 2010. Елена Викторовна Полевщикова. Каталог изданий XVI века: Из фондов Научной библиотеки ОНУ им. И. И. Мечникова. Одеса: Астропринт, 2010.

Polevščikova, Elena Viktorovna. 2013. Елена Викторовна Полевщикова. О начальном этапе формирования коллекции старопечатных изданий в фондах Научной библиотеки ОНУ им. И. И. Мечникова. Наукова бібліотека в сучасному суспільстві: історія, проблеми, перспективи. До 185-річчя наукової бібліотеки Одеського національного ун-ту ім. И. И. Мечникова. Одеса: Астропринт; 4857.

Ranjina, Dinko. 1891. Pjesni razlike. [Priredio Matija Valjavac.] Stari pisci hrvatski, XVIII. Zagreb: JAZU.

Rapacka, Joanna. 1998. Zaljubljeni u vilu: studije o hrvatskoj knjižeonosti i kulturi. Split: Književni krug.

Renouard, Antoine Augustin. 1834. Annales de l'imprimerie des Alde. Paris: Jules Renouard.

Rešetar, Milan. 1916. Bibliografski prilozi. »Građa za povijest književnosti hrvatske«, 8:462-468. 
Rešetar, Milan. 1920. Bibliografski prilozi II. »Građa za povijest književnosti hrvatske«, 9:42-63.

Rešetar, Milan. 1929. Redakcije i izvori Vetranovićeva Posvetilišta Abramova. »Rad JAZU«, 237:38-70.

Salzmann-Čelan, Marija. 1980/81. Marin Držić i Mavro Vetranović: o nekim rukopisima Posvetilišta Abramova. »Filologija«, 10:339-352.

Schmitz, Werner. 1977. Südslavischer Buchdruck in Venedig (16. - 18. Jahrhundert): Untersuchungen und Bibliographie. Giessen: Wilhelm Schmitz Verlag.

Schwarzenberg, Karl. 1972. Katalog der kroatischen, polnischen und tschechischen Handschriften der Österreichischen Nationalbibliothek. Wien: In Kommission bei Verlag Brüder Hollinek.

Sokolová, Františka. 1997. Cyrilské a hlaholské staré tisky v Českých knihovnách. Praha: Slovanská knihovna při Národní knihovně České republiky.

Stipčević, Aleksandar. 2005. Socijalna povijest knjige u Hrvata. Knjiga II: Od glagoljskog prootiska (1483) do hrvatskog narodnog preporoda (1835). Zagreb: Školska knjiga.

Stipčević, Aleksandar. 2008. Hrvatske knjige u inventaru Mletačkog tiskara i knjižara F. Brogiollija iz 1678. god. „Croatica et Slavica Iadertina«, 4:279-308.

Stipčević, Ennio. 2007. Otkrivena prva izdanja Držićevih djela u Milanu. »Forum«, 46:1057-1061.

Stipčević, Ennio. 2012. Pronađen Ljubmir (1580.) Dominka Zlatarića, prvi tiskani prijevod Aminte Torquata Tassa. »Forum«, 51:1069-1082.

Stipčević, Ennio. 2013. La prima traduzione a stampa dell' Aminta di Torquato Tasso: Ljubmir (1580) di Dominik Zlatarić. »Ricerche slavistiche«, 57:81-88.

Tatarin, Milovan. 2011. Čudan ti je animao čovjek: rasprave o Marinu Držiću. Zagreb - Dubrovnik: Zavod za povijesne znanosti HAZU.

Vekarić, Nenad. 1995. Pelješki rodovi. Svezak 1 (A-K). Dubrovnik: Zavod za povijesne znanosti HAZU.

Velikodnaja, Ana Vladimirovna i Elena Viktorovna Polevščikova. 2007. Анна Владимировна Великодная; Елена Викторовна Полевщикова. Редкие издания в книжном собрании А. Кухарского. »Вісник Одеського національного університету “ (Серія: Бібліотекознавство, бібліографознавство, книгознавство), 12.4:153-168.

Velikodnaja, Ana Vladimirovna. 2015. Анна Владимировна Великодная. Владельческие записи на книгах из собрания Анджея Кухарского. »Вісник Одеського національного університету« (Серія: 
Бібліотекознавство, бібліографознавство, книгознавство), 20.1:4965.

Williams, Franklin B., Jr. 1952. Special Presentation Epistles before 1641: A Preliminary Check-list. »The Library «, 5th series, 7.1:15-20.

Williams, Franklin B., Jr. 1962. Index of Dedications and Commendatory Verses in English Books Before 1641. London: The Bibliographical Society.

\title{
Variant Dedications in the Second Edition of Marin Držić's Tirena (1607)
}

\begin{abstract}
This essay studies the two dedicatory epistles normally associated with the second edition of Marin Držić's Tirena, published in 1607. One of these, printed only in part, is addressed to Vlaho Držić, while the other is addressed to Cardinal Silvestro Aldobrandini. It has been generally maintained that the dedication to Aldobrandini was never printed because it was attested in a single manuscript copy, produced by Ivan Kukuljević Sakcinski in 1840 from an unidentified source. Contrary to this view, a newly discovered copy of the 1607 edition of Tirena, to which attention is here drawn for the first time, proves that the dedication to Aldobrandini was in fact printed in full. The essay shows that this printed copy served as the basis for a mid-eighteenth-century manuscript codex of Držić's works put together by Miho Rastić, which has similarly escaped the notice of scholars. It is further shown that Rastićs manuscript was the direct source for Kukuljević's nineteenth-century transcript. A detailed bibliographical analysis of all the surviving exemplars of the second edition of Držić's Tirena reveals that the play was published in only one edition, but with variant dedicatory epistles. Despite the recently revived claims that Držić's works were published in Venice in a fourth edition in 1632, a fresh examination of the surviving evidence combined with new findings suggests that such claims are unfounded and that the edition from 1630 is at once the third and the last Venetian edition of Držić's works.

Ključne riječi: Marin Držić; Tirena; povijest izdavanja; posvetne poslanice; rukopisna predaja; mletački tisak; Francesco Bariletti; Marco Ginammi

Key words: Marin Držić; Tirena; history of publishing; dedicatory epistles; manuscript transmission; Venetian printing; Francesco Bariletti; Marco Ginammi
\end{abstract}

